\title{
Vertical structure of aerosols and water vapor over West Africa during the African monsoon dry season
}

\author{
S.-W. Kim ${ }^{1, *}$, P. Chazette ${ }^{1}$, F. Dulac ${ }^{1}$, J. Sanak ${ }^{1}$, B. Johnson ${ }^{2}$, and S.-C. Yoon ${ }^{3}$ \\ ${ }^{1}$ Laboratoire des Sciences du Climat et de l'Environnement, CEA-CNRS-UVSQ, Gif-Sur-Yvette, France \\ ${ }^{2}$ Met Office, Exeter, UK \\ ${ }^{3}$ School of Earth and Environmental Sciences, Seoul National University, Seoul, Korea \\ * now at: School of Earth and Environmental Sciences, Seoul National University, Seoul, Korea
}

Received: 27 October 2008 - Published in Atmos. Chem. Phys. Discuss.: 21 January 2009

Revised: 18 September 2009 - Accepted: 28 September 2009 - Published: 23 October 2009

\begin{abstract}
We present observations of tropospheric aerosol and water vapor transport over West Africa and the associated meteorological conditions during the AMMA SOP0 dry season experiment, which was conducted in West Africa in January-February 2006. This study combines data from ultra-light aircraft (ULA)-based lidar, airborne insitu aerosol and gas measurements, standard meteorological measurements, satellite-based aerosol measurements, airmass trajectories, and radiosonde measurements. At Niamey $\left(13.5^{\circ} \mathrm{N}, 2.2^{\circ} \mathrm{E}\right)$ the prevailing surface wind (i.e. Harmat$\tan$ ) was from the northeast bringing dry dusty air from the Sahara desert. High concentrations of mineral dust aerosol were typically observed from the surface to 1.5 or $2 \mathrm{~km}$ associated with the Saharan airmasses. At higher altitudes the prevailing wind veered to the south or southeast bringing relatively warm and humid airmasses from the biomass burning regions to the Sahel $\left(<10^{\circ} \mathrm{N}\right)$. These elevated layers had high concentrations of biomass burning aerosol and were typically observed between altitudes of $2-5 \mathrm{~km}$. Meteorological analyses show these airmasses were advected upwards over the biomass burning regions through ascent in Inter-Tropical Discontinuity (ITD) zone. Aerosol vertical profiles obtained from the space-based lidar CALIOP onboard CALIPSO during January 2007 also showed the presence of dust particles (particle depolarization $(\delta) \sim 30 \%$, lidar Ångström exponent $(L A E)<0$, aerosol backscatter to extinction ratio $\left.(B E R): 0.026 \sim 0.028 \mathrm{sr}^{-1}\right)$ at low levels $(<1.5 \mathrm{~km})$ and biomass burning smoke aerosol $(\delta<10 \%$, LAE: 0.6 1.1, BER: $0.015 \sim 0.018 \mathrm{sr}^{-1}$ ) between 2 and $5 \mathrm{~km}$. CALIOP data indicated that these distinct continental dust and biomass
\end{abstract}

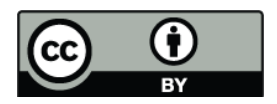

Correspondence to: S.-W. Kim (kimsw@air.snu.ac.kr) burning aerosol layers likely mixed as they advected further south over the tropical Atlantic Ocean, as indicated an intermediate values of $\delta(10 \sim 17 \%), L A E(0.16 \sim 0.18)$ and $B E R$ $\left(0.0021 \sim 0.0022 \mathrm{sr}^{-1}\right)$.

\section{Introduction}

The sub-Sahelian regions of West Africa are major a source of combustion-related biomass burning smoke aerosols. In addition, the nearby Sahara desert is a very large source of natural wind-blown mineral dust aerosol. Biomass burning aerosols exert a significant influence on the Earth's radiation budget by scattering and absorbing solar radiation (Haywood and Boucher, 2000; Eck et al., 2003; Keil et al., 2003; Magi et al., 2003; Myhre et al., 2003). Similarly, wind-blown dust aerosols exert significant influences on both the solar and the terrestrial radiation budgets (Haywood et al., 2003; Highwood et al., 2003; Kim et al., 2004; Won et al., 2004). Several field experiments have been conducted in the past to better understand the influence of these two types of aerosols on the regional climate of Africa. Mineral dust aerosols emitted from the African continent were studied in detail off the Atlantic coast of Africa during the Saharan Dust Experiment (SHADE) conducted in late September 2000 (Tanré et al., 2003). Similarly, biomass burning aerosols emitted from South Africa were studied within the framework of the Southern African Regional Science Initiative (SAFARI 2000) conducted during the August-September 2000 dry season (Swap et al., 2003).

The pattern of aerosol emissions, particularly biomass burning smoke, over West Africa is closely related to the seasonal north-to-south shift of the Inter-Tropical Convergence

Published by Copernicus Publications on behalf of the European Geosciences Union. 
Zone (ITCZ) (e.g. Cachier and Ducret, 1991; Sauvage et al., 2005; Haywood et al., 2008). Generally, dust storms occur throughout the year with their peak in springtime (Marticorena and Bergametti, 1996), whereas the anthropogenic emissions of biomass burning aerosols from the sub-Sahelian regions of North Africa peak during the dry season (i.e. from December to February; Sauvage et al., 2005; Haywood et al., 2008). Mixing of the biomass burning aerosol with dust was also observed during the 2006 dry season, leading to varied optical properties (Johnson et al., 2008).

In this study, we analyze data from aircraft-based and ground-based lidars and airborne in-situ aerosol and gas measurements performed over Niamey $\left(13.48^{\circ} \mathrm{N}, 2.17^{\circ} \mathrm{E}\right)$, Niger, during the first intensive field phase of the African Monsoon Multidisciplinary Analysis (AMMA; http://amma. mediasfrance.org/). This phase of AMMA, so-called SOP0 (Special Observation Period-0), in conjunction with Dust And Biomass Experiment (DABEX; http://badc.nerc.ac.uk/ data/dabex/), took place in the West African Sahel during the dry season in January-February 2006 (Haywood et al., 2008). The vertical distribution of dust and biomass burning aerosol and their associated optical, physical and radiative properties has been studied within the frameworks of AMMA SOP-0/DABEX using both airborne lidar and in-situ observations. For example, Chazette et al. (2007) demonstrated a new methodology for the retrieving of aerosol extinction coefficient profiles using lidar based on an ultralight aircraft (ULA). They give with one examples of the aerosol vertical distribution for both the dust and biomass burning aerosols. Osborne et al. (2008) and Johnson et al. (2008) investigated the physical and optical properties of dust and biomass burning aerosols and their radiative effects by using aircraft-based in-situ measurements (nephelometer, particle soot absorption photometer and optical particle sizers) measurements from 14 flights of the BAe-146 aircraft between 13 January to 3 February 2006. Raut and Chazette (2008) presented radiative budget calculations of multi-layered aerosols over Niamey in the UV-Visible range over the period 26 January $\sim 1$ February 2006 . The synoptic meteorological pattern observed during AMMA SOP0/DABEX was summarized by Haywood et al. (2008). This showed how horizontal and vertical motions in the atmosphere explain the vertical and geographic distributions of dust and biomass burning aerosol. This meteorological pattern was assumed to be typical of the dry season in West Africa. However, there was somewhat limited evidence to support the generality of this meteorological pattern, given the limited time period of the AMMA SOP-0/DABEX observations and lack of coordinated comparisons between the lidar and aircraft in-situ instruments.

The goal of our study is to investigate the synopticscale meteorological conditions and aerosol vertical distributions experienced over West Africa during the dry season and verify the general synopsis presented by Haywood et al. (2008). We examine the vertical distributions and transport of aerosol in further detail and make useful crosscomparisons between ground-based and airborne measurements from AMMA SOP-0/DABEX (2006) and space-based lidar measurements performed in January 2007. Section 2 provides simple descriptions of the instrumentation and data sets used in this study. Section 3 provides an overview of the meteorological transport pattern during the dry season. Section 4 presents observations of the multi-layered structure of aerosol layers and their associated transport patterns. Section 5 presents measurements from the spacebased lidar Cloud-Aerosol Lidar with Orthogonal Polarization (CALIOP) onboard Cloud-Aerosol Lidar and Infrared Pathfinder Satellite Observations (CALIPSO) during January 2007.

\section{2. Measurements and analysis}

\subsection{Aircraft-based measurements performed in January-February 2006}

\subsubsection{Instruments onboard an ultra-light aircraft (ULA)}

The Lidar Aérosol Ultra-Violet Aéroporté (LAUVA) lidar system onboard an ultra-light aircraft (ULA) was developed by the Commissariat à l'Energie Atomique (CEA) and the Centre National de la Recherche Scientifique (CNRS) and operated with a Nd:Yag laser at a wavelength of $355 \mathrm{~nm}$ with $1.5 \mathrm{~m}$ vertical resolution. Detailed descriptions of this instrument and its data retrieval procedures are provided in Chazette et al. (2007). In summary, we performed horizontal forward shooting during the ULA ascent and the descent, which directly gives access to the aerosol extinction coefficient $\left(\sigma_{e}\right)$ if the atmosphere can be supposed to be horizontally homogeneous from the lidar emitter to a target distance. The value of $\sigma_{e}$ was retrieved by using the well-known slope method (see Eq. 1):

$\sigma_{e}\left(z_{f}\right)=\frac{1}{2} \frac{\partial \ln \left[P\left(s, z_{f}\right)\right]}{\partial s}-\sigma_{m}\left(z_{f}\right)$

Where, $\sigma_{e}\left(z_{f}\right)$ denotes the $\sigma_{e}$ at flight altitude $\left(z_{f}\right), P\left(s, z_{f}\right)$ is the range-corrected signal at the horizontal distance $(s)$ between $s_{0}$ and $s_{1}$ along the lidar line of sight at $z_{f}$, and $\sigma_{m}\left(z_{f}\right)$, the molecular extinction coefficient at $z_{f}$. Here, the distance $s_{0}$ and $s_{1}$ is 0.4 and $1 \mathrm{~km}$, respectively. The horizontal homogeneity is verified by considering the linear character of the logarithm of the range-corrected signal against the distance between $s_{0}$ and $s_{1}$. The lidar ratio (i.e. backscatter to extinction ratio) profile retrieved from the coupling between airborne lidar horizontal and nadir-shooting measurements during AMMA SOP-0 was used in the inversion of lidar extinction profile. Details are given in the Sects. 3 and 5.2 of Chazette et al. (2007). The lidar return signals from the emitter/receiver up to $0.4 \mathrm{~km}$ were not inverted due to the overlap correction problem. During nighttime, the ULA 
wing was removed to allow upward shooting for continuous monitoring at ground level. Ground-based zenith and airborne nadir lidar data were inverted by using a well-known method based on Bernoulli's differential form of the propagation equation. This approach was successfully employed for lidar airborne (Chazette et al., 2007) or ground-based (Chazette, 2003) measurements.

A Personal DataRam (PdRam), which is a small portable nephelometer-type instrument documented in Dulac et al. (2001), measured aerosol side-scattering in the angular range of $45-95^{\circ}$ at the wavelength of $880 \mathrm{~nm}$ (bandwidth of $40 \mathrm{~nm}$ ) where the molecular scattering is negligible. The instrument was calibrated in terms of Mie scattering by using a gaseous reference scatterer. The PdRam was further calibrated in terms of aerosol extinction at $870 \mathrm{~nm}$ against a ground-based sunphotometer (Chazette et al., 2007).

\subsubsection{In situ aerosol and gas measurements on the FAAM BAe-146 aircraft}

The aerosol scattering $\left(\sigma_{s}\right)$ and absorption $\left(\sigma_{a}\right)$ coefficients were obtained by using a three-wavelength integrating nephelometer (TSI 3563; 450, 550, and $700 \mathrm{~nm}$ ) and a Radiance Research Particle Soot Absorption Photometer (PSAP, $567 \mathrm{~nm}$ ) on board the FAAM BAe-146 research aircraft. The aerosol size distributions were measured by using a Passive Cavity Aerosol Spectrometer Probe 100-X (PCASP). The PCASP radius range $(0.05 \sim 1.5 \mu \mathrm{m})$ is not sufficient to characterize the complete size distribution of dust or biomass burning aerosols. However, the shape of the measured distribution can reveal which type of particles is dominant (Johnson et al., 2008; Osborne et al., 2008). Details on the calibration of these instruments are provided in Johnson et al. (2008) and Osborne et al. (2008). The meteorological parameters of temperature $(T)$, relative humidity $(\mathrm{RH})$, wind speed (WD) and direction (WS) were also measured, in addition to carbon monoxide $(\mathrm{CO})$ and ozone $\left(\mathrm{O}_{3}\right)$ concentration. Details of FAAM flight operations during AMMA SOP-0 are given in Haywood et al. (2008).

\subsection{Space-borne active and passive sensor measurements}

\subsubsection{Space-borne lidar}

Launched in April 2006 after the AMMA SOP-0 campaign, the Cloud-Aerosol Lidar with Orthogonal Polarization (CALIOP), onboard Cloud-Aerosol Lidar and Infrared Pathfinder Satellite Observations (CALIPSO) satellite provides information on the vertical distribution of aerosols and clouds as well as on their optical and physical properties over the globe with unprecedented spatial resolution (Winker et al., 2007). The total attenuated backscattering intensity at 532 and $1064 \mathrm{~nm}\left(\beta_{532}^{\prime}\right.$ and $\left.\beta_{1064}^{\prime}\right)$ and particle depolarization ratio $(\delta$, defined as the ratio between perpendicular and parallel polarized backscatter signals) at the wavelength of $532 \mathrm{~nm}$ were analyzed in this study. Both the mean vertical profiles of aerosol extinction and backscatter coefficients $\left(\sigma_{532}\right.$ and $\beta_{532}$, respectively) at $532 \mathrm{~nm}$ are taken from the operational level-2 products. The averages are calculated for $40 \mathrm{~km}$ segments along the satellite ground track. The inversion for different sub-average lidar profiles uses the Klett method (Klett, 1981, 1985) and a look-up table including the layer-averaged aerosol backscatter-to-extinction ratio $(B E R)$. This approach is described in Young et al. (2008). It is then possible to derive the corresponding $B E R$ profile at $532 \mathrm{~nm}$ by the ratio $\left(\beta_{532} \div \sigma_{532}\right)$.

Between -0.5 and $8.2 \mathrm{~km}$ (between 8.2 and $20.2 \mathrm{~km}$ in parenthesis) above mean sea level (a.m.s.l.), they have $30 \mathrm{~m}$ $(60 \mathrm{~m})$ vertical and $333 \mathrm{~m}(1 \mathrm{~km})$ horizontal resolutions. The range-corrected and back-ground noise-subtracted lidar return signals (i.e. $\beta_{532}^{\prime}$ and $\beta_{1064}^{\prime}$ profiles) were obtained from the NASA Langley Research Center Atmospheric Science Data Center (ASDC; http://eosweb.larc.nasa.gov/) via online web orders. In this study, the lidar Angström exponent $(L A E)$ is calculated as $\ln \left(\beta_{1064}^{\prime} / \beta_{532}^{\prime}\right) \div \ln (532 / 1064)$. CALIOP observations have been available since June 2006 . We investigated data from the dry season in 2007 and selected the closest two orbits (January 7 and 18, 2007) to the Niamey site. We examined orbital tracks ranging from the desert areas around $20^{\circ} \mathrm{N}$ to the tropical Atlantic Ocean at the equator. Further information on the CALIOP instrumentation and its products can be found at http://www-calipso. larc.nasa.gov/.

\subsubsection{Passive space-borne instruments}

The Multi Angle Imaging Spectrometer (MISR) instrument onboard the Terra satellite provides estimates of aerosol optical depth using four channels at wavelengths of 446, 558, 672 , and $867 \mathrm{~nm}$ and cameras at nine different viewing angles. MISR has a spatial resolution of $250 \mathrm{~m}$ and provides aerosol retrievals without any limitations due to surface reflectance (Kahn et al., 2005). MISR covers the entire area of North Africa only every eight days due to its narrow swath width (about $210 \mathrm{~km}$ ), but has the unique advantage of being able produce AOD over the bright surfaces of the Saharan desert. The AOD retrieved from the MISR measurements over North Africa correlates well with TOMS/OMI UV aerosol index (Christopher et al., 2008), and compares well with AODs from AERONET cimel sun/sky radiometers (e.g. Kahn et al., 2005; Christopher et al., 2008). In this study, the MISR Monthly Global Level-3 Product (MISR MIL3MAE) AOD data over January and February 2006 are used to explain the spatio-temporal distributions of aerosols over West Africa, including the Saharan desert area, during the AMMA SOP-0 dry season experiment.

The Ozone Monitoring Instrument (OMI) is a new instrument installed onboard the Aura satellite; this instrument 
has a spatial resolution of $13 \mathrm{~km} \times 24 \mathrm{~km}$ and has produced data since August 2004. The Aerosol Index (AI) is derived from the difference between the wavelength dependence of reflected radiation in the presence of aerosols and under pure molecular atmospheric conditions, and it indicates the presence of ultraviolet (UV)-absorbing aerosols such as dust and smoke aerosols.

The fire identification product derived from the Advanced ATSR (Along-Track Scanning Radiometer) was used to locate regions of biomass burnings across North Africa. ATSR fire products are available since November 1995 (Arino et al., 2005). We obtained data from the ATSR sensor onboard ENVISAT for January-February of 2006 and 2007 from http://dup.esrin.esa.int/ionia/wfa/index.asp.

\subsection{Meteorological parameters}

Vertical profiles of temperature $(T)$, relative humidity $(\mathrm{RH})$, wind speed (WD) and direction (WS) were provided by operational upper air radiosondes launched at the Niamey international airport, Niger $\left(13.48^{\circ} \mathrm{N}, 2.17^{\circ} \mathrm{E}\right)$, by ASECNA (Agence pour la Sécurité de la Navigation Aérienne en Afrique et à Madagascar) four times a day (00:00, 06:00, 12:00, and 18:00 UTC).

Monthly mean NCEP/NCAR reanalysis data (Kalnay et al., 1996; Kistler et al., 2001) from January and February 2006 was also used to study the variation in 3-D wind fields from near the surface to mid troposphere. The reanalysis data had a horizontal resolution of $2.5^{\circ} \times 2.5^{\circ}$ and 17 pressure levels from $1000 \mathrm{hPa}$ to $10 \mathrm{hPa}$. We considered data at $925,850,700$ and $600 \mathrm{hPa}$ which roughly corresponded to altitude range of the different aerosol layers identified by the aircraft and lidar data.

Trajectory analysis was used to determine airmass transport routes. Back trajectories were calculated using the NOAA hybrid single particle lagrangian integrated trajectory (HYSPLIT) model (Draxler and Rolph, 2003) with 6-hourly archived meteorological data provided from the US National Centers for Environmental Prediction (NCEP) Global Data Assimilation System (GDAS). The altitude of the trajectory starting point was selected primarily from the lidar/in-situ observation of aerosol layer height. The water vapor mixing ratio (WVMR) along the airmass trajectory was retrieved by using the HYSPLIT model, which calculates meteorological parameters (i.e. temperature, relative humidity, pressure) along its trajectories. The WVMR given by the HYSPLIT model was in good agreement with those of balloon-borne data observed at an adjacent radiosonde site for each time step of the trajectory (Yoon et al., 2006).

\section{Aerosol optical depth and synoptic meteorological conditions}

The transport and vertical distribution of dust and biomass burning aerosols over West Africa during the dry monsoon season are closely linked to persistent circulation patterns such as the north-easterly Harmattan, the African Easterly Jet, and the south-westerly trade winds. We begin with a schematic overview of these relationships and the meteorological flow over West Africa during the AMMA dry season campaign.

Figure 1 illustrates the monthly mean AOD at $558 \mathrm{~nm}$ over West Africa determined from the MISR measurements and NCEP/NCAR reanalysis monthly mean wind vectors $\left(\mathrm{m} \mathrm{s}^{-1}\right)$ at $925 \mathrm{hPa}$, and NCEP/NCAR reanalysis monthly mean precipitation $\left(\mathrm{mm} \mathrm{day}^{-1}\right)$ and fire spots (red dots) from the ATSR sensor over west Africa for January (left) and February 2006 (right).

Two important synoptic features are the Intertropical Convergence Zone (ITCZ, pink dashed line in Fig. 1) and the Inter-tropical Discontinuity area (ITD, white solid line in Fig. 1). The ITCZ is the zone of confluence between the north-easterly wind on its northward side and southerly winds on its southern side. These winds flow from high pressure systems on either side of the equator; the Saharan anticyclone centered around $15^{\circ} \mathrm{N}-10^{\circ} \mathrm{E}$ and the south Atlantic subtropical anticyclone centered around $30^{\circ} \mathrm{S}-10^{\circ} \mathrm{W}$ (not shown). The ITCZ and its associated wind patterns and surface pressure features migrate southwards during the dry season (see Fig. 2 of Sauvage et al., 2005, for detailed overview). In Fig. 1b, the northern boundary of the ITCZ is shown, as determined from the northern edge of the band of high monthly mean precipitation rate. The heavy precipitation associated with the ITCZ results from the convergence of moist air in the lower troposphere, which is forced upwards leading to deep convection. It is worth noting that the geographical location of the atmospheric convergence varies with altitude. For example, the airmasses at $850 \mathrm{hPa}$ converge at slightly lower latitudes than those at $925 \mathrm{hPa}$ (Cachier and Ducret, 1991). The ITD marks the near-surface convergence zone (below $2000 \mathrm{~m}$ altitude; Sauvage et al. 2007) between the harmattan wind coming from the Sahara and the monsoon flow coming from the Gulf of Guinea (Parker et al., 2005; Sauvage et al., 2005; Cuesta et al., 2008; Haywood et al., 2008; Knippertz et al., 2009). The location of the ITD in Fig. 1 was determined from the convergence of the wind at $925 \mathrm{hPa}$.

High AODs are observed to the north and south of the ITD in Fig. 1a. These high AODs are presumably related to a combination of wind-blown mineral dust aerosols from the Saharan desert area (e.g. Osborne et al., 2008) and biomass burning aerosol (e.g. Johnson et al., 2008) originating from the fires to the north of the ITCZ, as indicated by ATSRderived fire spots in Fig. 1b. The ATSR-derived fire locations in January-February 2006 showed almost identical spatial 
(a)

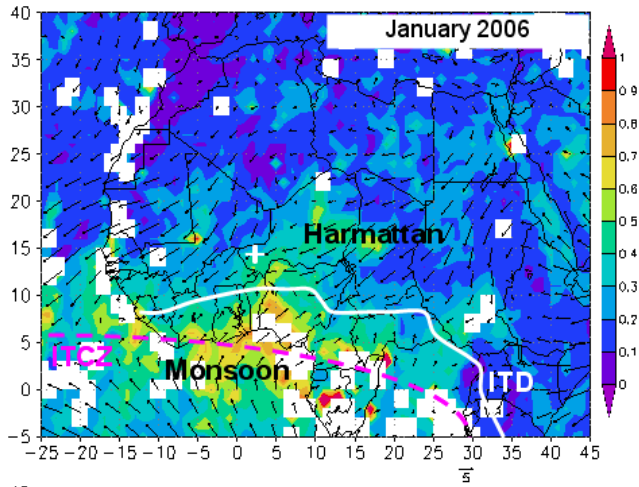

(b)

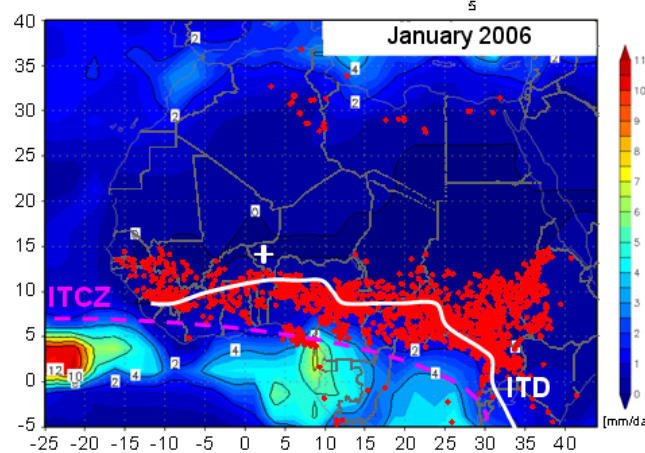

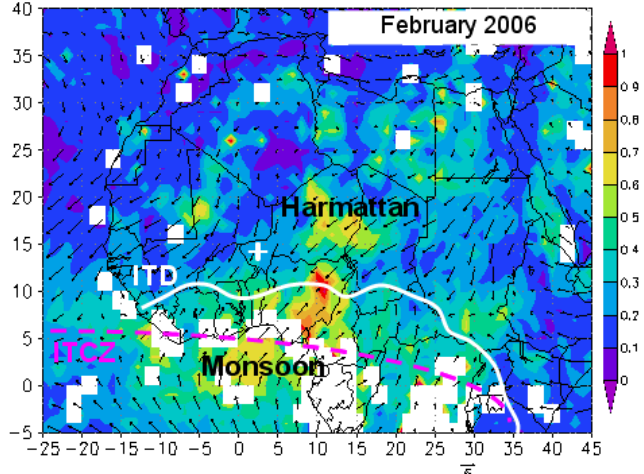

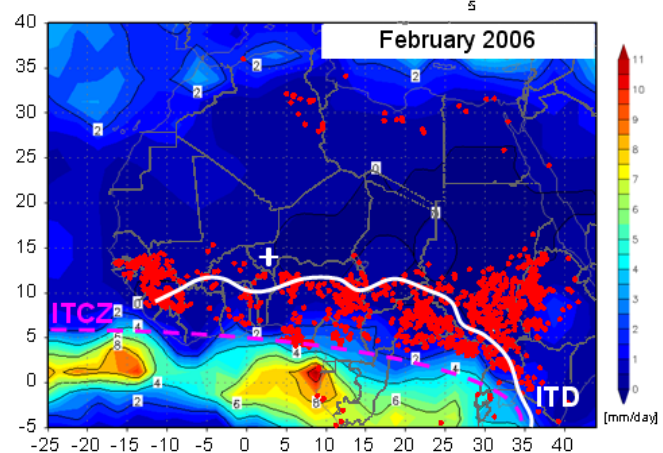

Fig. 1. (a) Monthly mean AOD at $558 \mathrm{~nm}$ determined from satellite MISR measurements and monthly mean NCEP/NCAR reanalysis wind vectors $\left(\mathrm{m} \mathrm{s}^{-1}\right)$ at $925 \mathrm{hPa}$. (b) NCEP/NCAR reanalysis monthly mean precipitation $(\mathrm{mm} /$ day) and fire spots (red dots) from the ATSR sensor. Data are from January (left column) and February 2006(right column). The wind vector's reference scale is given at the bottom right of each figure. The locations of Inter-tropical Discontinuity (ITD, white solid line) and the northern boundary of Inter-tropical Convergence Zone (ITCZ, pink dashed line) are superimposed. The white crosshair indicates the location of Niamey $\left(13.48^{\circ} \mathrm{N}, 2.17^{\circ} \mathrm{E}\right)$, Niger.

distributions to those of MODIS as well as of 10-yr ATSR observations (not shown). The biomass burning fires are due to a combination of natural and agricultural burns (Cachier and Ducret, 1991; Haywood et al., 2008).

Figure 2 shows monthly mean fields of vertical velocity (omega; Pascal s${ }^{-1}$ ) and wind vectors $\left(\mathrm{m} \mathrm{s}^{-1}\right)$ from the NCEP/NCAR reanalysis for four pressure levels $(600,700$, 850 and $925 \mathrm{hPa}$ ) over West Africa for January (left column) and February 2006 (right column). Strong subsidence occurs over most of the Sahara (i.e. positive omega value) between 600 and $925 \mathrm{hPa}$, whereas ascent (i.e. negative omega value) occurs over the Sahel at latitudes ranging from $5^{\circ} \mathrm{N}$ to $10^{\circ} \mathrm{N}$ and between pressure levels of 850 and $925 \mathrm{hPa}$. This region of strong lower tropospheric ascent corresponds with the ITD and overlaps considerably with the region of fire spots shown in Fig. 1b. This coincidence provides favorable conditions for the uplift of biomass burning emissions into the lower free troposphere. This supports the conceptual scheme shown by Figs. 6 and 14 of Sauvage et al. (2007) whereby the meridional and vertical circulation pattern during the dry season carries combustion products into the lower parts of troposphere by strong rising motion in the ITD.

The $600 \mathrm{hPa}$ and $700 \mathrm{hPa}$ wind patterns show a strong easterly flow south of $10^{\circ} \mathrm{N}$ corresponding to the African easterly jet (AEJ). This AEJ (grey shaded area in 700 and $600 \mathrm{hPa}$ levels of Fig. 2) is a thermal wind responding to temperature gradients between the warm Sahara desert area and the cool Gulf of Guinea in southern-west Africa and is usually located around $700 \sim 650 \mathrm{hPa}$ (Sauvage et al., 2005). At latitudes north of $15^{\circ} \mathrm{N}$ the prevailing winds are westerly. If the uplifted biomass burning aerosols reach to the altitude of the AEJ then it will generally transport them westwards leading to a large outflow of biomass burning aerosol over the Atlantic ocean at around $10^{\circ} \mathrm{N}$ (as observed in Capes et al., 2008).

\section{Vertical profiles of aerosol and thermodynamic variables}

\subsection{Ground-based lidar measurements at Niamey}

A multi-layered aerosol structure was frequently observed with the LAUVA system at Niamey airport during the AMMA SOP-0 campaign. Figure 3a shows the temporal evolution of aerosol extinction coefficient $\left(\sigma_{e}\right)$ and of the lidar-derived AOD at a wavelength of $355 \mathrm{~nm}$ during nighttime operations at Niamey, Niger, on 31 January to 

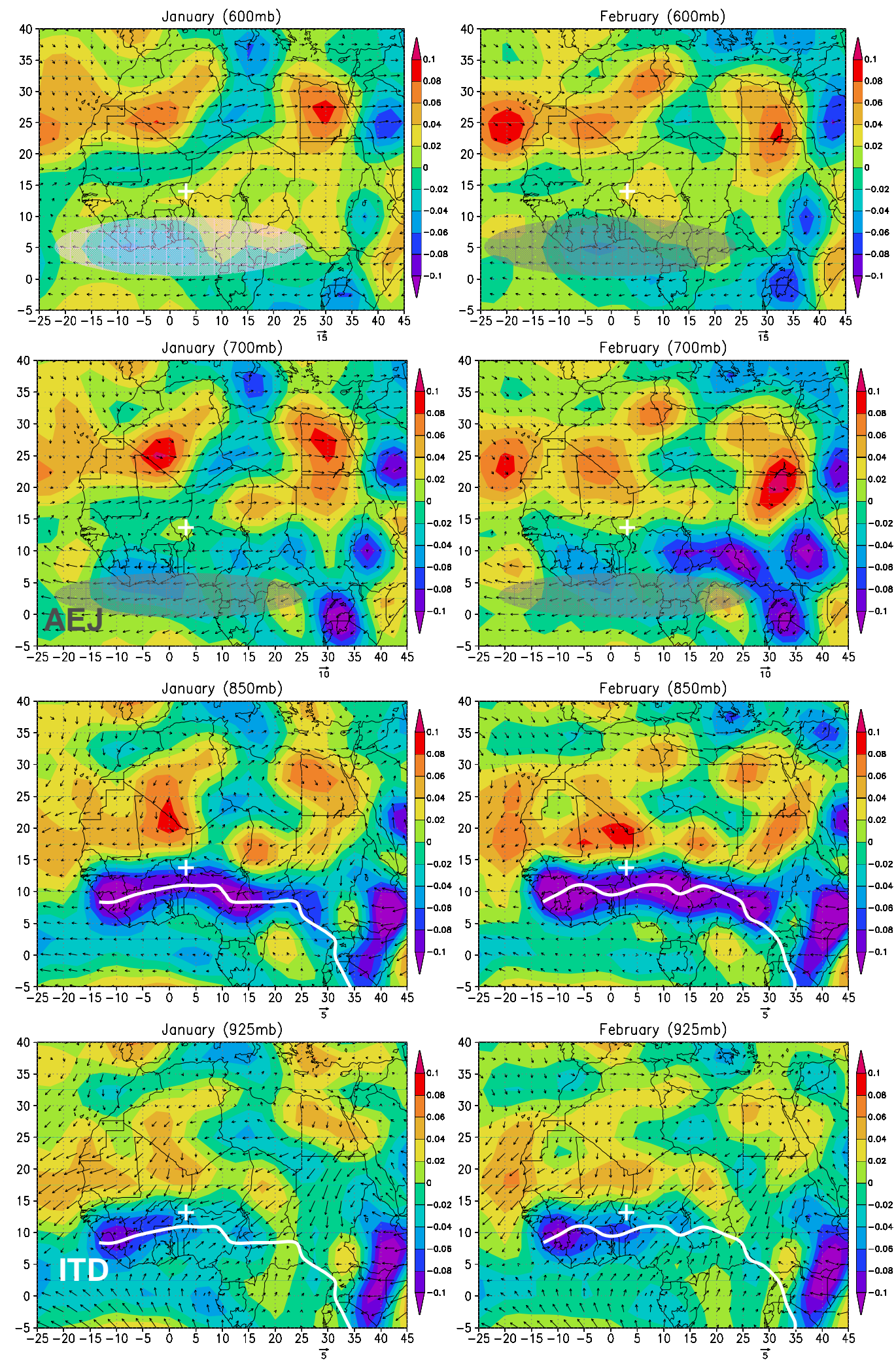

Fig. 2. Monthly mean vertical velocity (omega; Pascal s ${ }^{-1}$ ) and horizontal wind vector $\left(\mathrm{m} \mathrm{s}^{-1}\right)$ for four pressure levels $(600,700,850$ and $925 \mathrm{hPa}$ ) from NCEP/NCAR reanalysis for January (left column) and February 2006 (right column). The locations of ITD (white solid line at 925 and $850 \mathrm{hPa}$ ) and African Easterly Jet (AEJ, grey shaded area at 700 and $600 \mathrm{hPa}$ ) are superimposed. Note that the wind vector's reference scale shown at the bottom right of the figure is different for each altitude. 
(a)

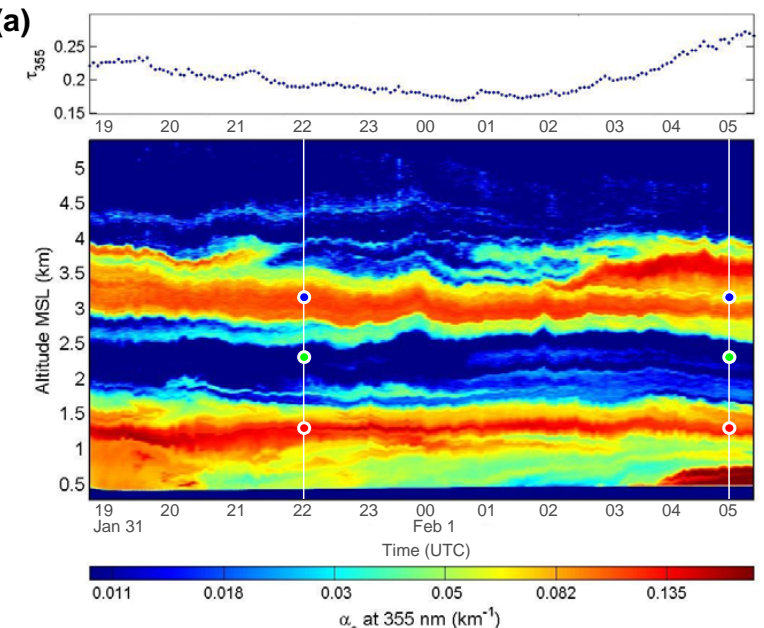

(b)

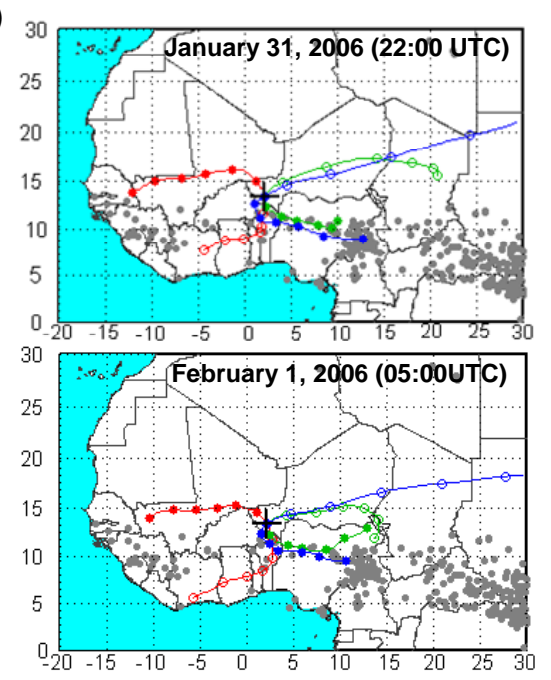

(c)
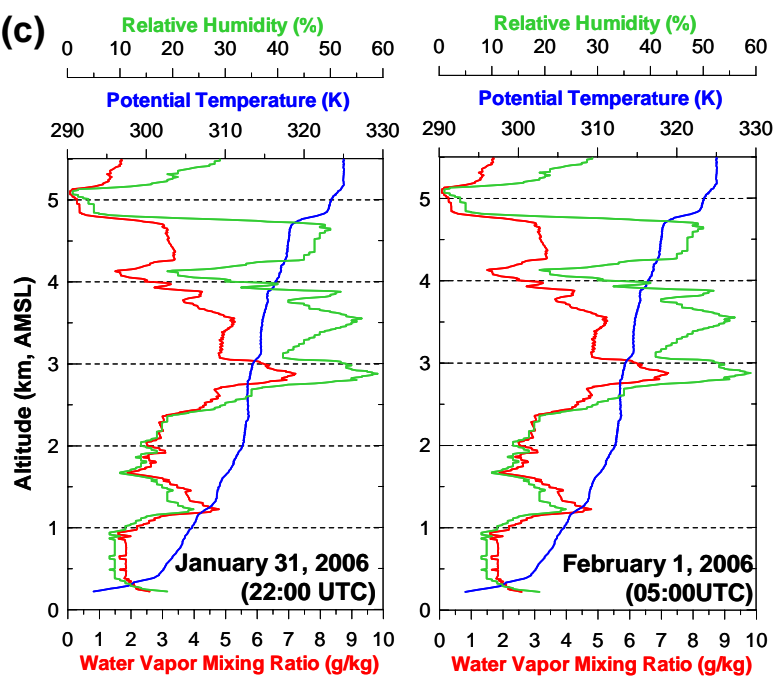

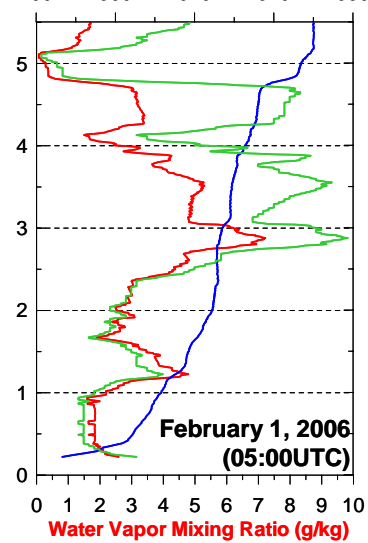

Fig. 3. (a) Aerosol extinction coefficient (lower panel) and aerosol optical depth (upper panel) at $355 \mathrm{~nm}$ from the ULA-based lidar at Niamey, Niger, during the nighttime of 31 January to 1 February 2006. Circular symbols mark the starting altitudes and times of modeled trajectories shown in panel b. (b) Four-day backward (closed symbols) and forward (open symbols) trajectories of airmasses starting from heights of $1.2 \mathrm{~km}$ (red), $2.3 \mathrm{~km}$ (green), and $3.1 \mathrm{~km}$ (blue) at Niamey at 22:00 UTC on 31 January 2006 (upper panel) and 05:00 UTC on 1 February 2006 (lower panel). ATSR-derived fire locations are superimposed as grey dots. (c) Relative humidity (green line), water vapor mixing ratio (red line), and the potential temperature ( $\theta$, blue line) at Niamey airport observed by the balloon-borne radiosonde.

1 February 2006. Two scattering aerosol layers are shown at approximately $2.5-4 \mathrm{~km}$ and altitudes below $2 \mathrm{~km}$. These are separated by a clean intermediate layer between about 2 and $2.5 \mathrm{~km}$.

Figure $3 \mathrm{~b}$ shows four-day backward (closed symbols) and forward (opened symbols) trajectories of airmasses arriving at Niamey at altitudes of 1.2, 2.3, and $3.1 \mathrm{~km}$ at 22:00 UTC on 31 January 2006 and at 05:00 UTC on 1 February 2006. The three starting altitudes of the trajectories are selected from the lidar profiles and represent the center of each airmass mentioned above (see Fig. 3a). The backward airmass trajectory computations (closed symbols) show that the elevated aerosol layer originated from the biomass burning regions to the southeast, as indicated by the ATSR-derived fire locations. This implies that the upper aerosol layer in Fig. 3a is likely to be dominated by the biomass burning aerosols. The lowermost aerosol layer identified in Fig. 3a, airmass was transported from the desert area in Mali, as shown by the red trajectory with closed symbols in Fig. 3b. This airmass traveled from west to east at the latitude of approximately $15^{\circ} \mathrm{N}$, and then turned southwards passing over the Niamey site (crosshair). Given the origin of the airmass the lower aerosol layer is likely to be dominated by mineral dust, although some input of biomass burning 
aerosol seems likely as the back-trajectory passes close to some fire spots. However, such a trajectory analysis cannot account for the mixing of aerosols from preceding days (e.g. Knippertz et al., 2009). As shown by the forward trajectory (red line with opened symbols), this low-level dust layer was transported in a south/south-west direction from Niamey towards the Atlantic Ocean. The trajectory corresponding to the clean air seems to follow a similar path to that of the biomass burning airmass and it is unclear why this air did not become mixed with the biomass burning aerosol. A thin layer of remarkably clean air was also identified (but thinner) by Chazette et al. (2007) south of Niamey down to Benin on 29-30 January 2006, sandwiched between the dust and biomass burning aerosol layers. Such a situation was also reported over Southern Africa during the dry biomass burning season (Hobbs, 2002, 2003) within the framework of the Southern African Regional Science Initiative (SAFARI2000) campaign. These clean air slots, frequently found during SAFARI-2000, descended from the free troposphere due to widespread subsidence associated with the continental anticyclone over Southern Africa, and influence vertical displacements of aerosols (Hobbs, 2002, 2003). The static stability of a clean air slots inhibit the intrusion of turbulent eddies (carrying aerosols or pollutants) from above or below (Hobbs, 2003). However, for this case over West Africa, it is difficult to clearly identify the origin of the clear air through meteorological analyses. Prevailing winds and backward trajectories indicate that the clean air layer in Fig. 3a originated from the same biomass burning source area as the aerosol layer above. Although the vertical resolution of the HYSPLIT trajectory model may have been not sufficient for tracing the transport of such a thin airmass, both biomass burning and clean airmasses progressively rise before arriving at the Niamey (see the bottom panel of Fig. 7b).

Figure $3 \mathrm{c}$ shows a plot of the relative humidity $(\mathrm{RH})$, water vapor mixing ratio (WVMR), and potential temperature $(\theta)$ observed at Niamey airport by the balloon-borne radiosonde measurements. The lowermost troposphere, containing the mineral dust aerosol layer and the intermediate clear layer, is relatively dry $(\mathrm{RH}<25 \%)$, whereas the elevated layer of biomass burning aerosols is relatively more humid $(\mathrm{RH} \approx 30-$ $60 \%$ ). Absolute values of humidity (i.e. WVMR) are also higher within the biomass burning aerosol layer than in the air above and below it. Furthermore, there are steep gradients in $\theta$ at the upper parts of the dust and biomass burning aerosol layers $(\sim 1.2$ and $4.7 \mathrm{~km}$, respectively). As discussed by Kim et al. (2004), the greater water vapor in the biomass burning aerosol layer contributes to a higher radiative heating, increasing the potential temperature and static stability of the layer. This may help to maintain the structure of the layer for a longer period of time.

\subsection{Airborne lidar and in-situ measurements}

We present two cases (26 January and 1 February 2006) of the vertical structure of aerosols that combine data from the LAUVA and PdRam onboard the ULA and in-situ aerosol (i.e. particle counters/sizers, 3-wavelengths nephelometer, PSAP), gas (i.e. carbon monoxide and ozone analyzer) instruments, and standard meteorological sensors (temperature, pressures, and relative humidity) onboard the BAe146. Figure 4 a shows the LAUVA-derived $\sigma_{e}(355 \mathrm{~nm})$ and PdRam-measured aerosol scattering coefficient $\left(\sigma_{s}, 880 \mathrm{~nm}\right)$ vertical profiles during the ascending and descending flights (ULA flight \#6: 07:09 09:03 UTC) over Niamey airport on 26 January 2006. The Ångström exponent ( $\AA$; 450/700 nm) profile was calculated from the nephelometer onboard BAe146 (flight B163 P2: 08:10 08:34 UTC). The elevated biomass burning aerosol layer and dusty near-surface layer were clearly discernable above and below approximately $1.5 \sim 1.6 \mathrm{~km}$, as indicated by the difference in the wavelength dependence of $\sigma_{s}$ (i.e. $\AA>1.2$ for the elevated biomass burning aerosol layer and $\AA \sim 0.5$ for the dust-laden nearsurface layer). The aerosol size distributions, measured by the Passive Cavity Aerosol Spectrometer Probe 100-X (PCASP) onboard BAe-146 (B163 P2: 08:10 08:34 UTC) were averaged over 1000-m thick layers and are shown in Fig. 4d. Compared to the aerosol size distribution measured at $4 \sim 5 \mathrm{~km}$, relatively large particles (radius $>0.2 \mu \mathrm{m}$ ) were much more abundant near the surface (i.e. ground $\sim 1 \mathrm{~km}$ and $1 \sim 2 \mathrm{~km}$ ), whereas small particles (radius $<0.2 \mu \mathrm{m}$ ) were more abundant in the elevated layers (i.e. $2 \sim 3 \mathrm{~km}$ and $3 \sim 4 \mathrm{~km})$. The profiles of ozone $\left(\mathrm{O}_{3}\right)$ and carbon monoxide (CO) concentrations are given in Fig. 4b. The pronounced increases in their concentration above $1.6 \mathrm{~km}$ provides further evidence that the elevated aerosol layer is associated with biomass burning emissions (e.g. Johnson et al., 2008). The three water vapor mixing ratio (WVMR) profiles, measured by the BAe-146, ULA, and radiosonde meteorological sensors in the morning of 26 January 2006, show excellent agreement (Fig. 4c). These show higher levels of WVMR within the elevated biomass burning layer. The low WVMR values near the surface are associated with a dry dusty airmass. Interestingly, both $\mathrm{O}_{3}$ and $\mathrm{CO}$ concentrations and WVMR showed almost identical vertical structures with that of the LAUVA-derived $\sigma_{e}$ (Fig. $4 \mathrm{a}$ ) above $1.5 \mathrm{~km}$. According to Sauvage et al. (2005) and Capes et al. (2008), biomass burning is responsible for high monthly mean concentrations of lower-tropospheric $\mathrm{O}_{3}$ and $\mathrm{CO}$ during the dry season over West and Central equatorial Africa, respectively.

Figure 5 shows another example of a complex layered aerosol structure obtained from the flights of the ULA (flight \#17: 07:31 09:11 UTC) and BAe-146 (flight B166 P1: 11:05 11:21 UTC) on 1 February 2006. Again there is a dry dust layer at low levels and a more humid layer with biomass burning aerosol above. Relatively low values of $\AA$ (0-0.5) below $1.0 \mathrm{~km}$ clearly indicate the presence of a 

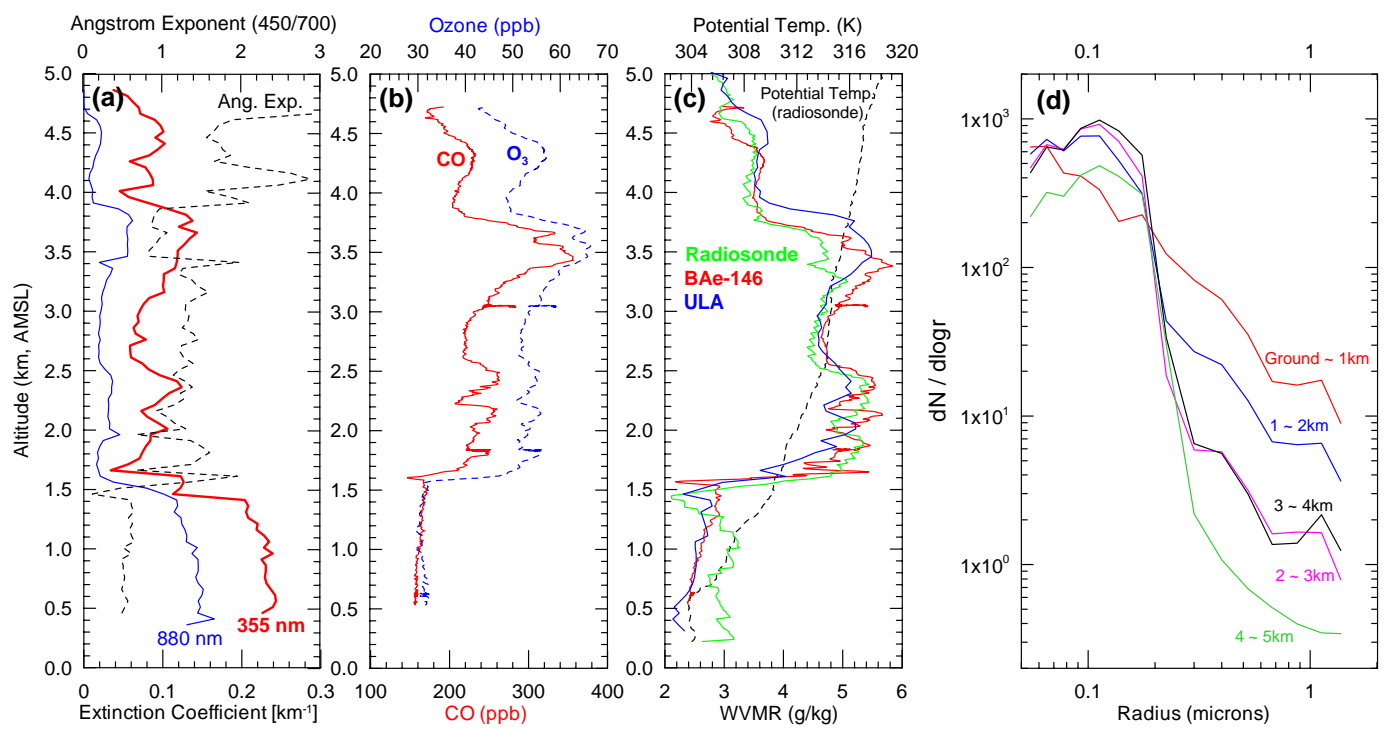

Fig. 4. Vertical profiles over Niamey airport on 26 January 2006: (a) aerosol extinction coefficient at $355 \mathrm{~nm}$ and $880 \mathrm{~nm}$ from the ULA-based lidar and PdRam, respectively (ULA flight \#6: 07:09 09:03 UTC), and Ångström exponent (450/700 nm) measured by the nephelometer onboard BAe-146 (B163 P2: 08:10 08:34 UTC). (b) Ozone and carbon monoxide concentrations from the BAe-146, (c) water vapor mixing ratio and potential temperature from the BAe-146 and radiosonde launched at Niamey airport (10:00 UTC). (d) Aerosol size distributions from the PCASP instrument, averaged over 1000-m thick layers during the BAe-146 flight (B163 P2: 08:10 08:34 UTC).
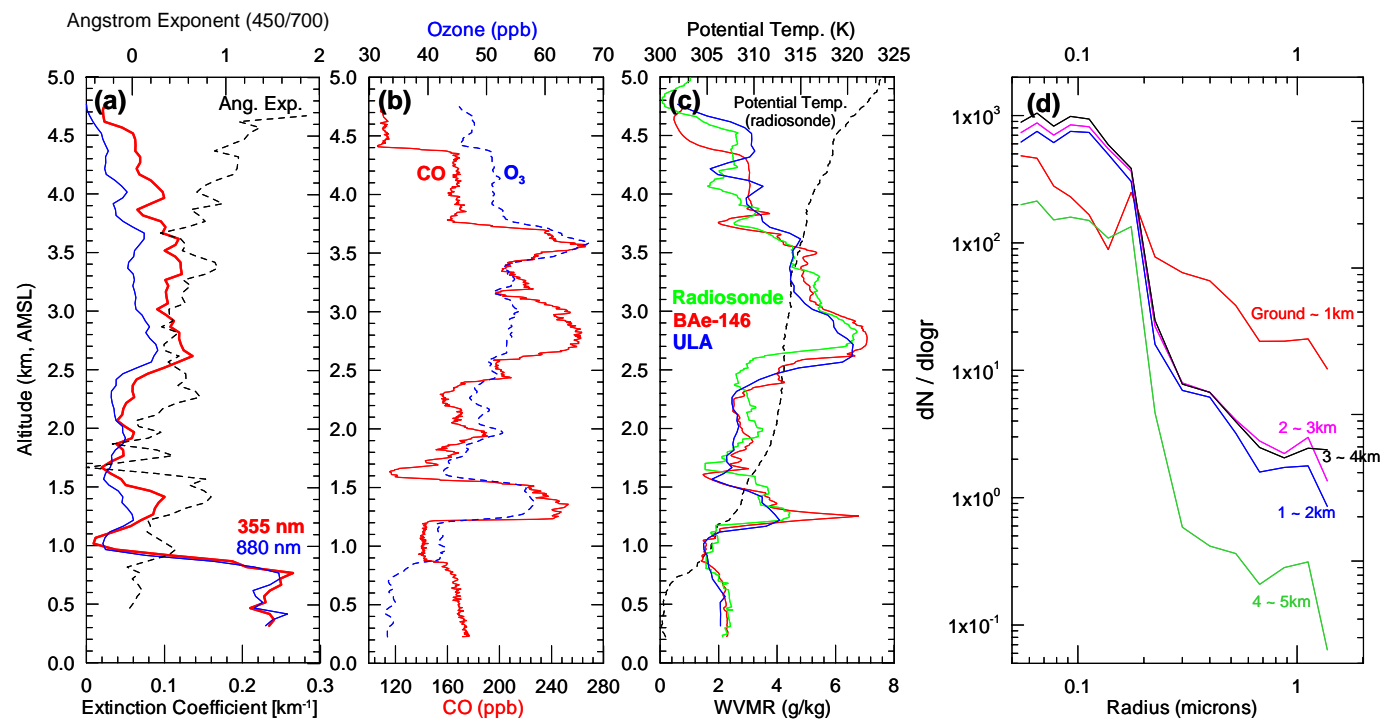

Fig. 5. Same as Fig. 4, except for the flights of the ULA (\#17: 07:31 09:11 UTC) and BAe-146 (B166 P1: 11:05 11:21 UTC) on 1 February 2006 .

mineral dust-rich layer. The relatively high values of $\AA$ (1-2) and increased concentrations of $\mathrm{O}_{3}$ and $\mathrm{CO}$ pinpoint the two biomass burning layers at $1.0-1.6 \mathrm{~km}$ and $1.6-4.4 \mathrm{~km}$. Note that the change in $\AA$ is not as abrupt as the case mentioned above because of several thick and thin elevated aerosol layers above the surface dust layer. These conclusions are supported by the PCASP data in Fig. 5d. This shows high concentration of large particles in the layer from the surface $-1 \mathrm{~km}$ (indicating dust), and an increase in fine particles in the upper layers (indicating biomass burning aerosol). The LAUVA-derived $\sigma_{e}, \mathrm{O}_{3}$ and $\mathrm{CO}$ concentrations, and WVMR show very similar features in their vertical structures across the two biomass burning layers showing a high level of correspondence between these quantities. 
Figure 6a shows six vertical profiles of both $\sigma_{e}$ at $550 \mathrm{~nm}$ and $\AA$ at 450 and $700 \mathrm{~nm}$ (left panel), $\mathrm{CO}$ and $\mathrm{O}_{3}$ concentrations (middle panel), and WVMR (right panel) obtained from the BAe-146 over Niamey from 23 January to 30 January 2006. In addition, the WVMR profile (orange line) was obtained by averaging the radiosonde measurements at $\mathrm{Ni}$ amey airport before, during, and after the BAe-146 flights. Figure $6 \mathrm{~b}$ shows the averaged vertical profiles and the associated standard deviations from all the profiles given in Fig. 6a, plus the profiles from flights B163 P2 (Fig. 4) and B166 P1 (Fig. 5). These profiles consistently indicate the presence of dry mineral dust aerosols at low levels and elevated layers of humid biomass burning aerosols. The $\sigma_{e}$ exhibits higher values in the dust-rich layers $(<1.5 \mathrm{~km})$ with low values of $\AA(<0.3)$. Secondary peaks of $\sigma_{e}$ and large values of $\AA$ in the upper aerosol layer $(>1.5 \mathrm{~km})$ indicate the presence of biomass burning aerosol layers. This pattern is well supported by a broad increase in the $\mathrm{O}_{3}$ and $\mathrm{CO}$ concentrations in the upper aerosol layer. These results suggest that there is no significant mixing of the biomass burning aerosol into the local surface layer near Niamey, although some partial mixing could occur at the boundary between the two layers. The slight increase in $\mathrm{CO}$ concentrations generally observed near the surface comparatively to a minimum between 1 and $1.5 \mathrm{~km}$ in altitude (Figs. 5b, 6a-b) may be attributed to local emissions from house heating and cooking by using charcoal and wood in Niamey area. Similarly, both aircraft-based and radiosonde-derived WVMRs are systematically enhanced within the elevated biomass burning aerosol layer as compared to the dust-rich near-surface layer. The origin of water vapor within an elevated biomass burning aerosol layer is discussed in the next section.

\subsection{Entrainment process of water vapor into elevated biomass burning aerosol layers}

In this section we examine the reason for the higher levels of WVMR relative to the biomass burning aerosol layer located above the dust layer. Figure 7a shows an example of the vertical profiles of the radiosonde-derived WVMR (red line) and WVMR calculated using the HYSPLIT model (crosshair). Figure 7a reveals that the WVMR derived by the HYSPLIT trajectory model fits well with the WMVR observed by radiosonde as shown over East Asia (e.g. Yoon et al., 2006). The airmass history for this case, starting at 05:00 UTC on 1 February 2006 at Niamey, is given in Fig. 3b. As shown in Fig. 7b, the WVMR within the elevated airmass (indicated by blue lines) increased during the period of time $72-36 \mathrm{~h}$ before reaching Niamey. This occurred while the airmass was at lower altitudes $(2-3 \mathrm{~km})$ over the biomass burning regions to the southeast (see Fig. 3b). The relatively moist airmass is advected upwards through an ascending motion associated with the convection in the ITD area (Fig. 2). As we discussed in Sect. 3, the ITD exists between the pole-ward low-level branch of the thermal cell and the equator-ward low-level branch of the Hadley cell (namely the Harmattan in the northern hemisphere). These two low-level cells cause gradients in surface temperature and humidity, the warmer dry surface being located pole-ward of the ITD and the cooler wet surface equator-ward of the ITD. Those gradients induce a thermal meridional and vertical circulation cell (Sauvage et al., 2007), which help in the ascent of moist air. If the uplifted biomass burning aerosols reach to the altitude of the AEJ (located around 700 650 hPa), it will generally transport them westwards leading to a large outflow of biomass burning aerosol over the Atlantic Ocean. The buoyancy associated with individual fires may have had relatively small effect on the vertical transport of the biomass burning aerosol compared to this large-scale circulation. This supposition would be in agreement with conclusions from other works (e.g. Labonne et al., 2007; Haywood et al., 2008).

A similar entrainment process of water vapor into the elevated biomass burning aerosol layer is also reported in Fig. 8, which provides further examples from flights B164 P2 on 28 January 2006 (Fig. 8a) and B165 P1 on 30 January 2006 (Fig. 8b; see also Fig. 6a). The three-day backward trajectories began from 12:00 UTC on 28 January 2006 at an altitude of $2700 \mathrm{~m}$ and from 05:00 UTC on 30 January at an altitude of $3000 \mathrm{~m}$. These two altitudes were selected to represent the center of the elevated biomass burning aerosol layer based on the airborne nephelometer measurements of $\sigma_{s}$ (Fig. 6a). The trajectories (upper left panel) for both cases can be traced back to the biomass burning areas. Further, the WVMR values calculated using the model are in good agreement with those of the balloon-borne observations (see lower left panel in each case). As found in Fig. 7, the enhancement of WVMR within the elevated biomass burning aerosol layer is initiated over the biomass burning areas (see two right panels in Fig. 8a and b).

\section{Space-borne CALIOP observations in the 2007 dry season}

In this section we extend our study to include space-based active (CALIOP) and passive (OMI) measurements from January 2007. This takes advantage of CALIPSO that was launched in April 2006 after the AMMA SOP-0 campaign (Winker et al., 2007). Here, we discuss how the vertical structure and associated optical properties of dust and biomass burning aerosols evolve during large-scale transport over the region. This section discusses two cases CALIOP measurements over West Africa during January 2007.

\subsection{Case 1: 7 January 2007}

The first case is the night-time observation of CALIOP on 7 January 2007. Figure 9a shows the Aura OMI-derived daily mean absorbing Aerosol Index at $340 \mathrm{~nm}\left(\mathrm{AI}_{340}\right)$ on 6 January 2007 and the ground track of CALIPSO on 
(a)
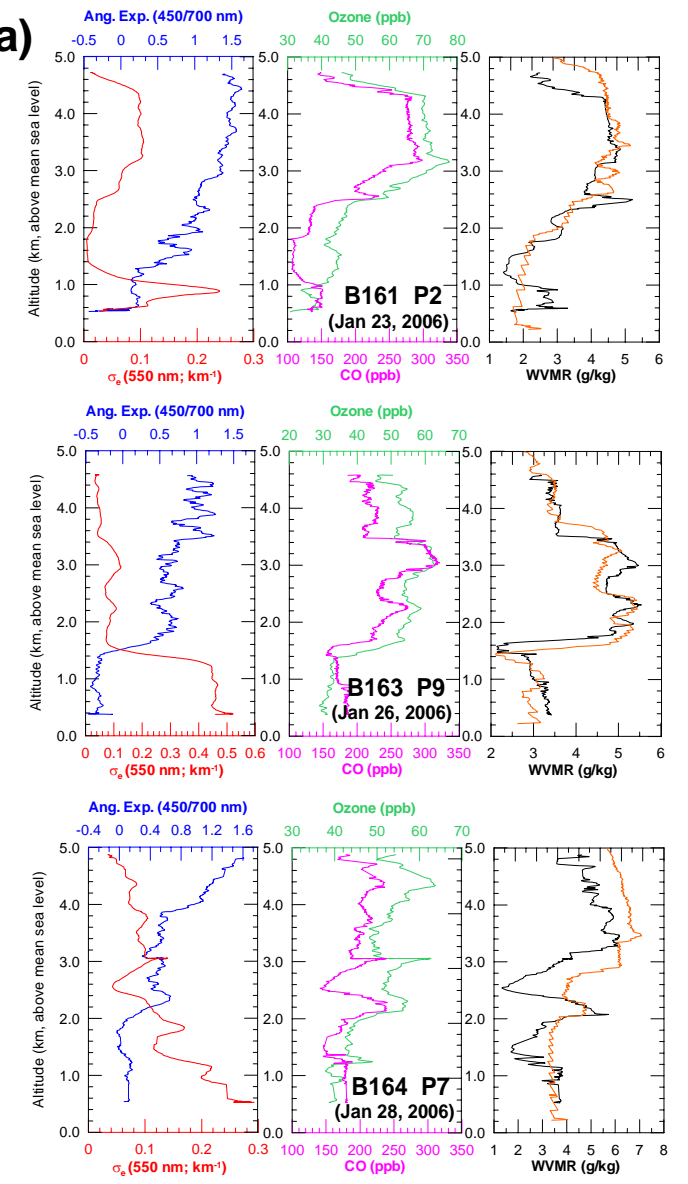

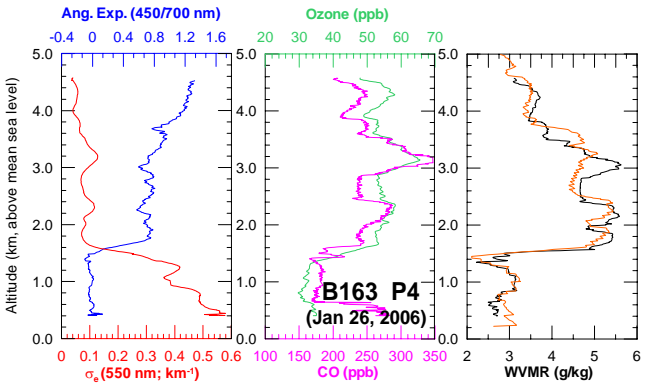

Ang. Exp. $(450 / 700 \mathrm{~nm}) \quad$ Ozone (ppb)

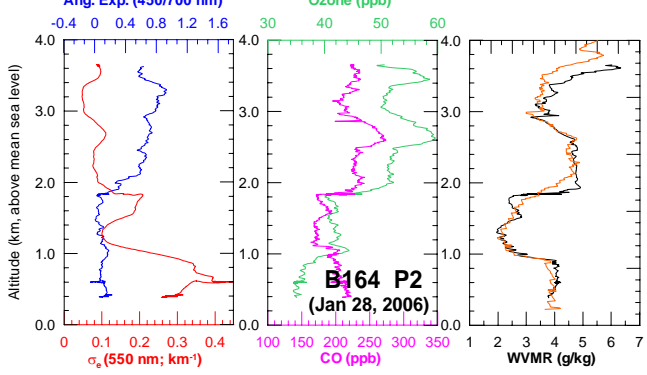

Ang. Exp. $(450 / 700 \mathrm{~nm}) \quad$ Ozone (ppb)

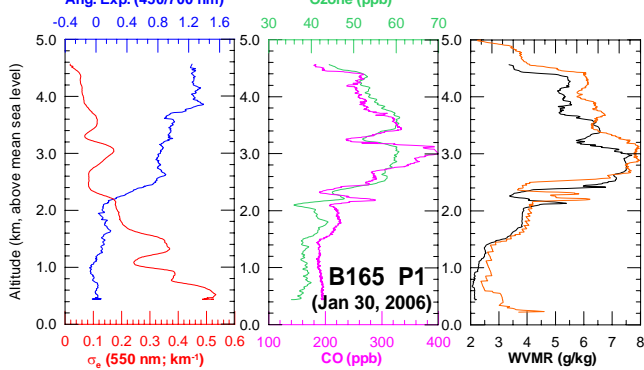

(b)

b) Angstrom Exponent (450/700 nm)

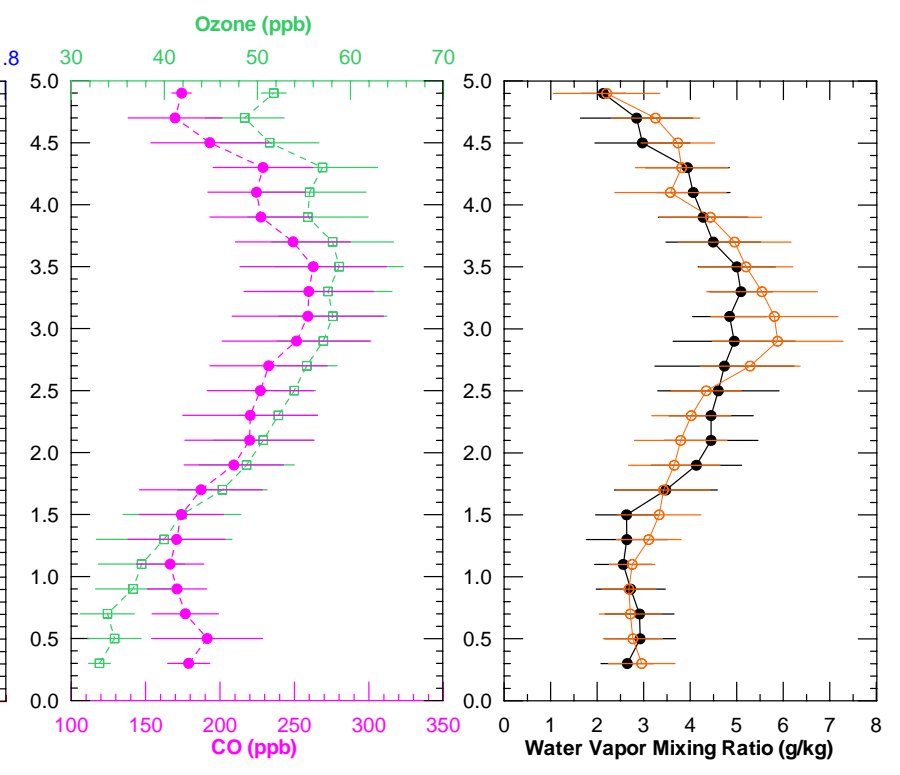

Fig. 6. Vertical profiles of aerosol extinction, Ångström exponent (450/700 nm), ozone, CO, and water vapor mixing ratio from (a) six flights of the BAe-146 and (b) averaged profiles from the BAe-146 during eight flights. All flights performed over Niamey from 23 January to 1 February 2006. The water vapor mixing ratio profiles indicated by orange lines were obtained from the radiosounding at Niamey airport before, during, and after the BAe flights. 

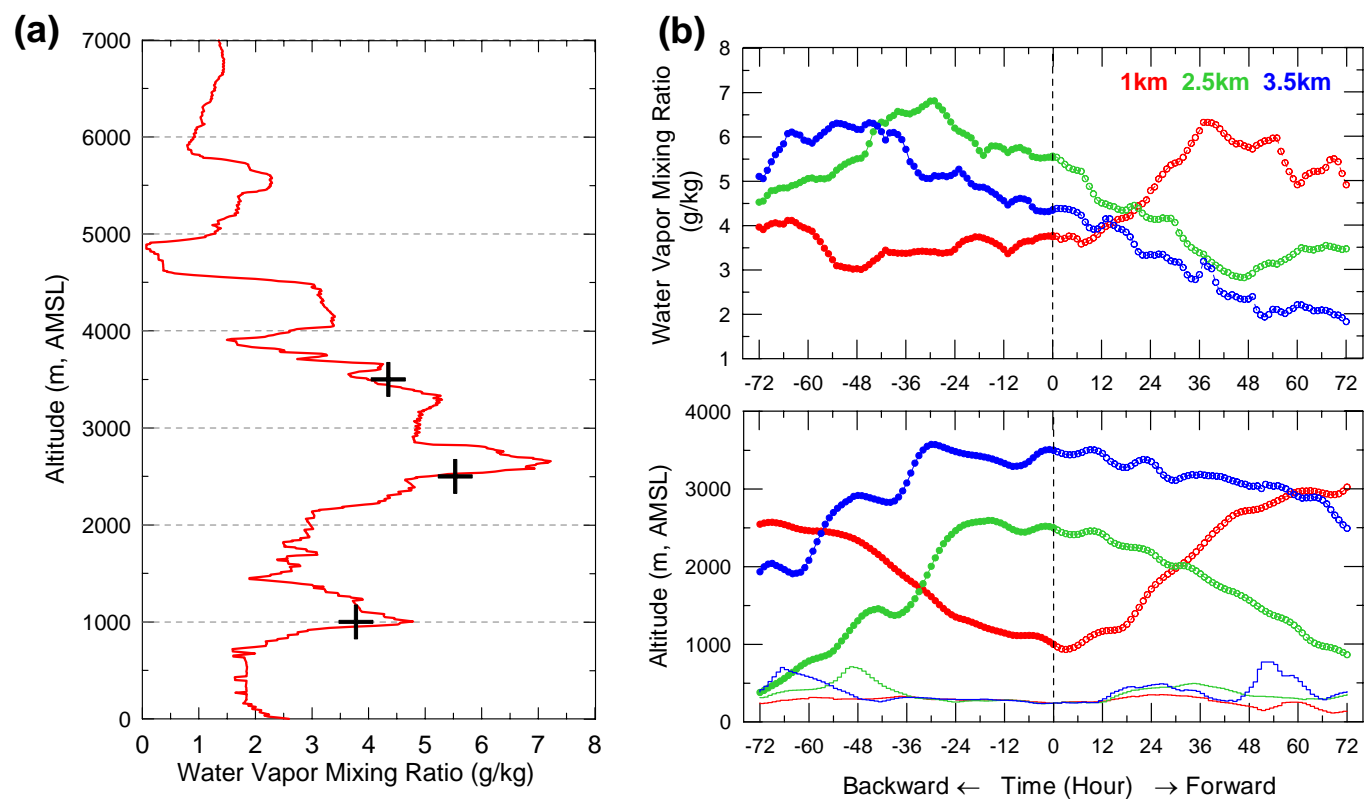

Fig. 7. (a) Vertical profile of radiosonde-derived water vapor mixing ratio and water vapor mixing ratio (crosshair) calculated by the trajectory model. (b) Trajectory model calculations of the heights of airmasses and water vapor mixing ratio along the trajectories at 05:00 UTC on 1 February 2006 at Niamey, Niger. The solid lines at the bottom inside (b) represent the ground elevation along the trajectories.

7 January 2007 (01:45 UTC). The CALIPSO track intersects the centre of a highly absorbing aerosol plume with $\mathrm{AI}_{340}$ values of 3-4.5 over a large area extending from about 2$18^{\circ} \mathrm{N}$. Figure $9 \mathrm{~b}$ shows the altitude-orbit cross-section of the total attenuated backscattering intensity at $532 \mathrm{~nm}\left(\beta_{532}^{\prime}\right)$ along the CALIPSO track. The space-based lidar CALIOP reveals the multiple-layered structure of the aerosol plume, and distinct differences in the vertical distribution between the southern and northern portions of the plume. The ability to discriminate such vertical structures (under cloud-free conditions) is the distinct advantage of active sensors, i.e. lidar over passive satellite remote sensing (e.g. Winker et al., 2007; Kim et al., 2008). Although the space-based lidar returned signal should be attenuated as it propagates downward, the vertical structure of atmospheric aerosols can still be retrieved with reasonable accuracy (e.g. Kim et al., 2008; see Fig. 10).

Figure 10 shows selected vertical profiles of $\beta_{532}^{\prime}$ and $\beta_{1064}^{\prime}$, depolarization ratio $(\delta)$ at the wavelength of $532 \mathrm{~nm}$, lidar Ångström exponent (LAE) and $\sigma_{532}$ for six locations (points " $A$ "-" $F$ " marked in Fig. 9b). The $\beta^{\prime}$ and $\sigma_{532}$ profiles from point " $A$ " to point " $D$ " (over land), show a multilayer aerosol structure with a thick aerosol layer at low levels (approximately below $1.5 \mathrm{~km}$ ) and a superposition of one or more scattering aerosol layers between 2 and $5 \mathrm{~km}$. The comparison between $\beta^{\prime}$ and $\sigma_{532}$ profiles shows good agreement both in the layer top and bottom structures of elevated biomass burning aerosol and dust-rich surface layers. Values of $\sigma_{532}$ in the elevated aerosol layer, between points
" $A$ "-" $D$ ", were mostly below $0.2 \mathrm{~km}^{-1}$, whereas values in the surface-layer reached about $0.4 \sim 0.6 \mathrm{~km}^{-1}$. The $\delta$ and $L A E$ profiles for points " $A$ "- $D$ " clearly indicate mineral dust aerosols at low levels and biomass burning aerosol in the elevated layers. Spherical particles do not generate a depolarized signal, whereas non-spherical (solid) particles such as dust or cirrus clouds show particle depolarization. The dustrich layer has a low $L A E$ ( $\leq 0$ in this case) due to large-size dust particles, whereas the elevated biomass burning aerosol layers have relatively high values of $L A E$ due to combustionrelated small-sized particles. Layer-averaged values of $\delta$, $L A E$ and aerosol backscatter-to-extinction ratio $\left(B E R ; \mathrm{sr}^{-1}\right)$ for each aerosol layer are summarized in Table 1, along with the top and bottom heights of each layer identified in Fig. 10. The value of $\delta$ for the near-surface dust layer ranges from $26.8 \%$ to $31.0 \%$, but that for elevated biomass burning layers range from $8.0 \%$ to $11.2 \%$. The value of $\delta$ for the aerosolfree mid troposphere region $(>6 \mathrm{~km}$ ) is approximately $2.0 \%$. These values of $\delta$ for mineral dust layers at low levels correspond well to previously reported values for wind-blown Sahara dust: for example, Freudenthaler et al. (2008) showed dust particle depolarization ratios of between 0.27 and 0.35 at $532 \mathrm{~nm}$ and a mean of 0.31 for pure dust during the Saharan Mineral Dust Experiment (SAMUM) period. The values of $\delta$ for Sahara dust in several locations of the Mediterranean region were up to $50 \%$, and even higher depolarization ratios have often been retrieved at sites closer to the dust source (Gobbi et al., 2003, 2004; Tafuro et al., 2006). The CALIOP-derived LAE for the dust-laden layer is less than 
(a)
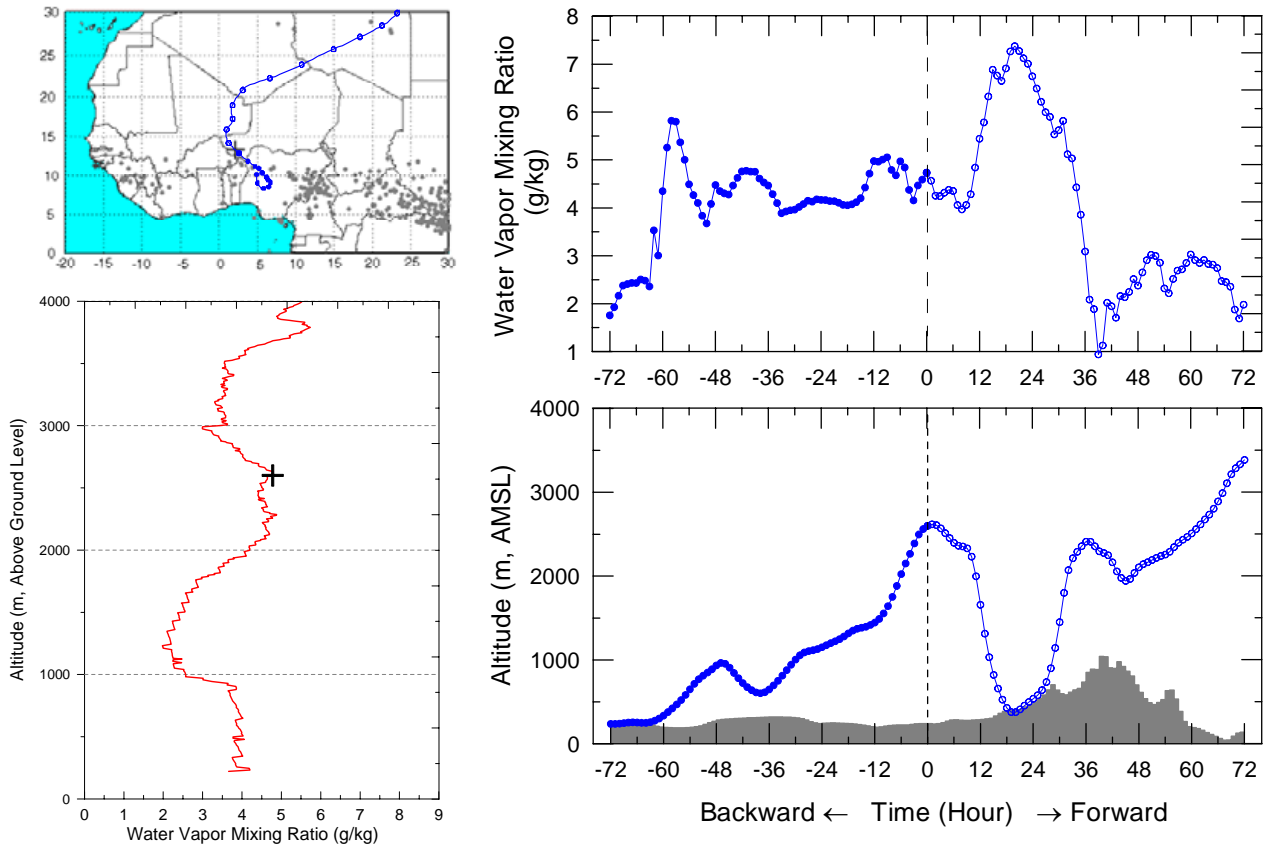

(b)
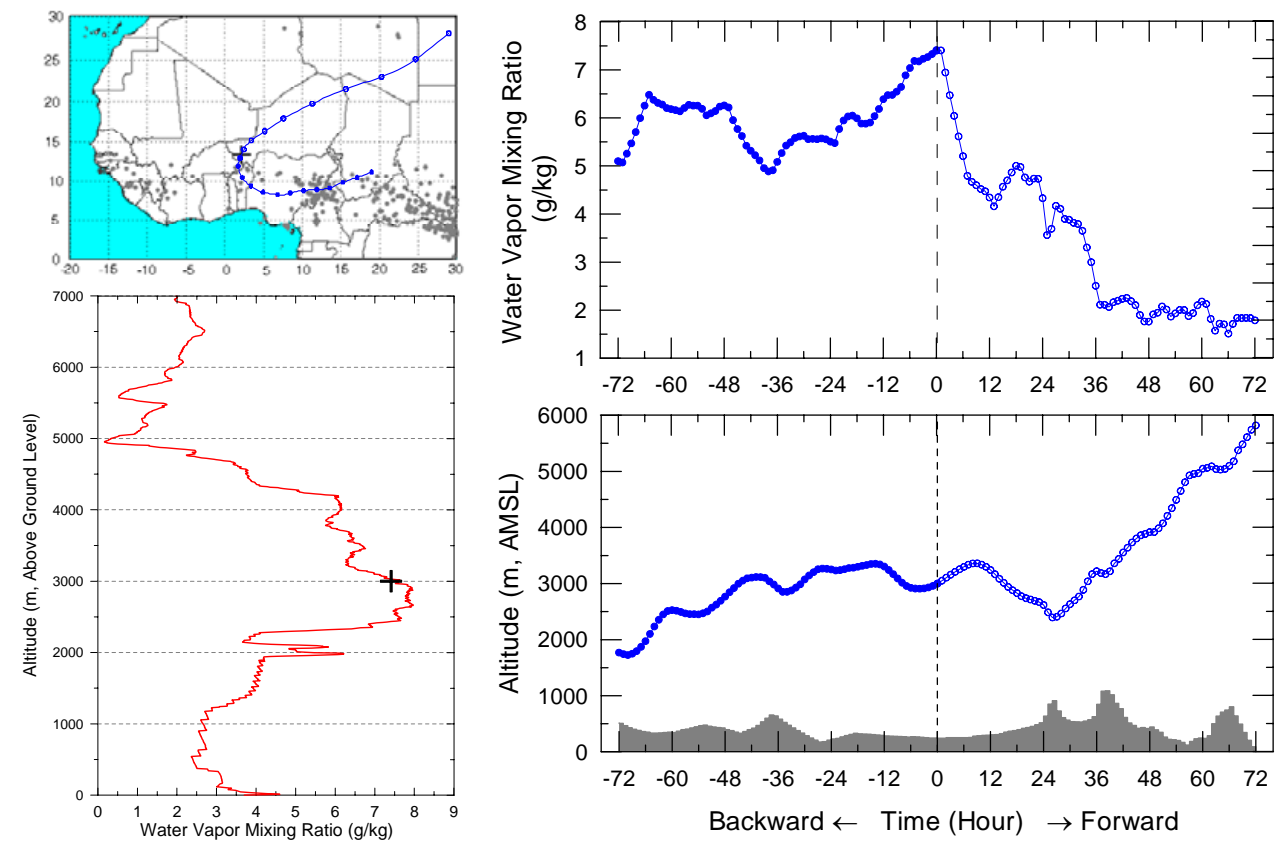

Fig. 8. Three-day airmass trajectory started at Niamey, Niger, at (a) 12:00 UTC on 28 January 2006 (flight B164 P2) and (b) 05:00 UTC on 30 January 2006 (flight B164 P1). ATSR fire locations are indicated by grey dots (upper left panels). Radiosonde-derived water vapor mixing ratio and water vapor mixing ratio (crosshair) calculated by the trajectory model are shown in lower left panels. Trajectory model calculations of the heights of the airmass and water vapor mixing ratio along the trajectories are shown in right panels with gray shaded area representing the ground elevation along the trajectory.

zero, but the $L A E$ for the elevated aerosol layer is greater than approximately 0.35 . Freudenthaler et al. (2008) show a mean Ångström exponent of 0.18 for dust, and a range of values between 0.04 and 0.34. Cattrall et al. (2005) estimate
Ångström exponent indirectly from sky radiance and solar transmittance measurements and report values of 0.1 for dust and 1.8 of biomass burning aerosol. The layer-averaged $B E R$ values for points " $A$ "- $D$ " clearly indicate differences 
(a)

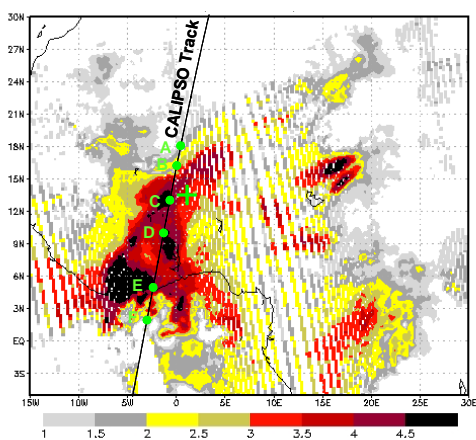

(b)

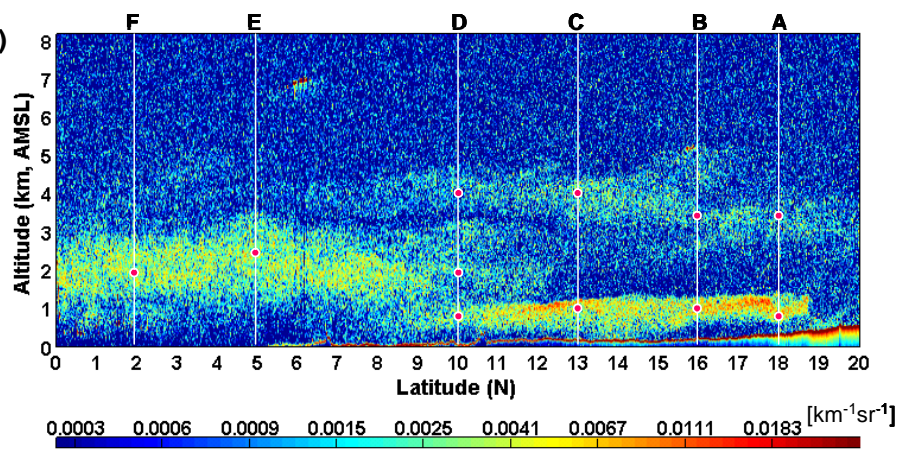

Fig. 9. Case 1: (a) Aura OMI-derived daily mean UV aerosol index over West Africa on 6 January 2007 and nighttime descending ground track of CALIPSO at approximately 01:45 UTC on 7 January 2007. The green crosshair represents the location of the Niamey airport. (b) The altitude-orbit cross-section of the total attenuated backscattering intensity along the CALIPSO track (from equator to $20^{\circ} \mathrm{N}$ ) given in (a). A to $\mathrm{F}$ indicate locations where detailed profiles are shown in Fig. 10. Red dots in (b) indicate starting points of trajectories shown in Fig. 11.

Table 1. Aerosol layer heights and optical properties from CALIOP for January 2007 case studies. ${ }^{1}$

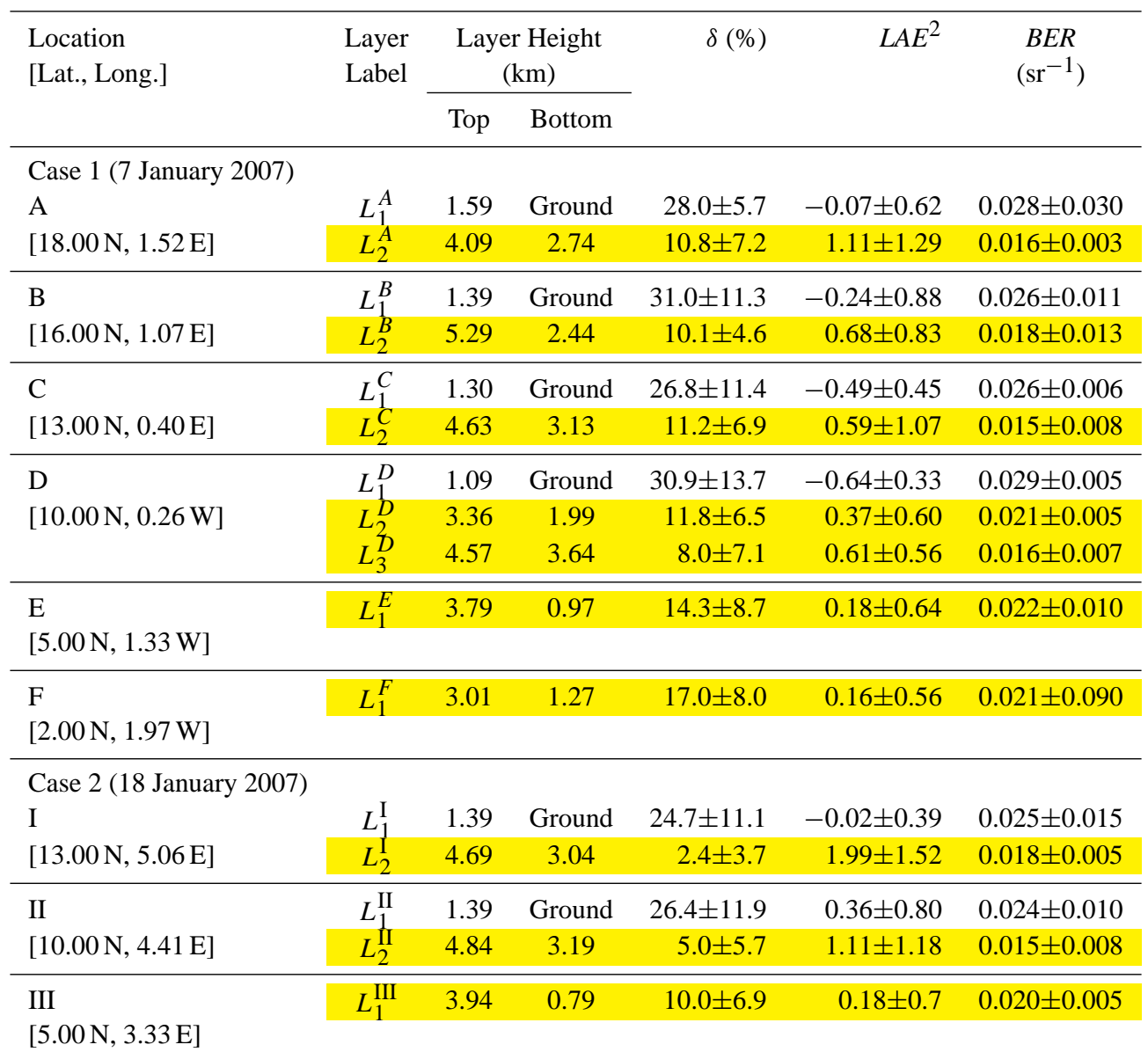

${ }^{1}$ Layers with yellow shading correspond to elevated aerosol layer.

2 The lidar Ångström exponent $(L A E)$ is calculated as $\ln \left(\frac{\beta_{1064}^{\prime}}{\beta_{532}^{\prime}}\right) \div \ln \left(\frac{532}{1064}\right)$. 

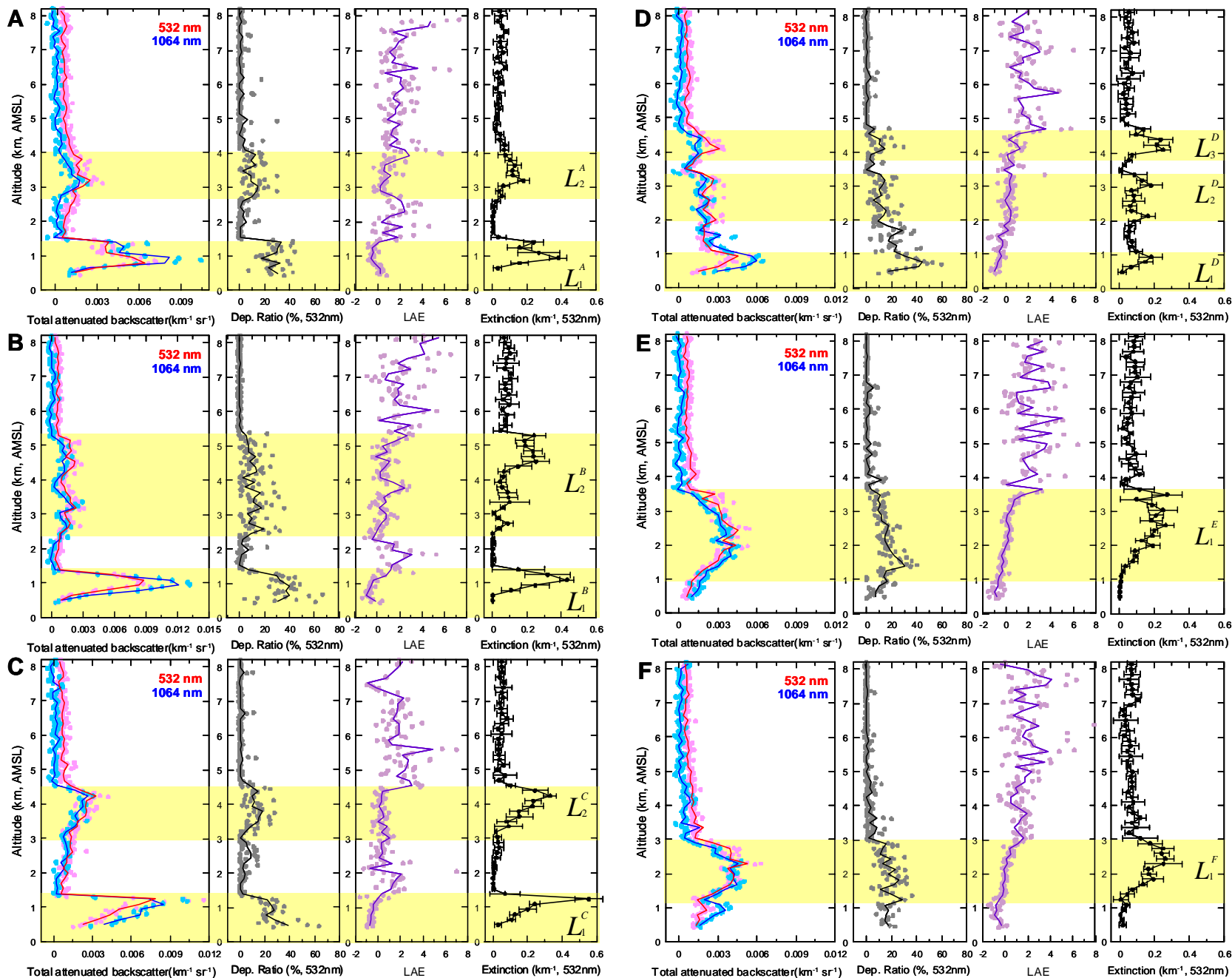

Fig. 10. Selected vertical profiles of the total 532-nm and 1064-nm attenuated backscatter (left), depolarization ratio (middle left), lidar Ångström exponent ( $L A E$, middle right) and aerosol extinction coefficient (right) for six different locations along the CALIPSO track indicated in Fig. 9. The dots are the average of CALIOP-derived 20 instantaneous profiles, which corresponds to a sampling duration of $1 \mathrm{~s}$ and an horizontal coverage of approximately $6.6 \mathrm{~km}$, and the lines are profiles smoothed at intervals of $150 \mathrm{~m}$ in the vertical.

in the nature of the aerosols between elevated and surface layers. From point " $A$ " to " $D$ " mean values of $B E R$ are in the range $0.015 \sim 0.018 \mathrm{sr}^{-1}$ in the elevated biomass burning aerosol layer, and $0.026 \sim 0.028 \mathrm{sr}^{-1}$ in the dust-rich surface layer. These values are consistent with previous measurements reported in the literature. Cattrall et al. (2005) reported $B E R$ values of 0.016 and $0.023 \mathrm{sr}^{-1}$ at $550 \mathrm{~nm}$ for the biomass burning and desert dust aerosols, respectively. Léon et al. (2003) also report $B E R$ values of $0.024 \pm 0.007 \mathrm{sr}^{-1}$ at $532 \mathrm{~nm}$ for the desert aerosols during the Saharan dust experiment (SHADE).

In regions near the coast or over the ocean (i.e. $<9^{\circ} \mathrm{N}$ ), a single relatively thick aerosol layer is apparent above the clear marine atmospheric boundary layer. This layer resides between approximately $1-4 \mathrm{~km}$ near the coast and $1-3 \mathrm{~km}$ over the ocean (see $\beta^{\prime}$ and $\sigma_{532}$ profiles at points " $E$ " and
" $F$ " in Fig. 9, respectively). The layer-averaged value of $\sigma_{532}$ is close to $0.2 \mathrm{~km}^{-1}$, which is intermediate between the elevated aerosol layer and dust-rich surface layer at points " $A$ " " $D$ ". The layer-averaged values of $\delta$ for the profiles at points " $E$ " and " $F$ " are $14.3 \%$ and $17.0 \%$, respectively. These values are not only intermediate between values for the low level mineral dust layer and the biomass burning aerosol layers at points " $A$ " to " $D$ ", but also are lower than those of dust particles (e.g. Freudenthaler et al., 2008). The $L A E$ values at points " $E$ " and " $F$ " are lower than those in the elevated layers at points " $A$ " to " $D$ " as well as those reported 1.8 for biomass burning aerosol by previous studies (e.g. Cattrall et al., 2005), indicating an increasing dominance of coarse particles. In addition, the layer-averaged $B E R$ value of $0.0021 \sim 0.0022 \mathrm{sr}^{-1}$ found at points " $E$ " and " $F$ " is intermediate between the values obtained for the mineral dust layer 

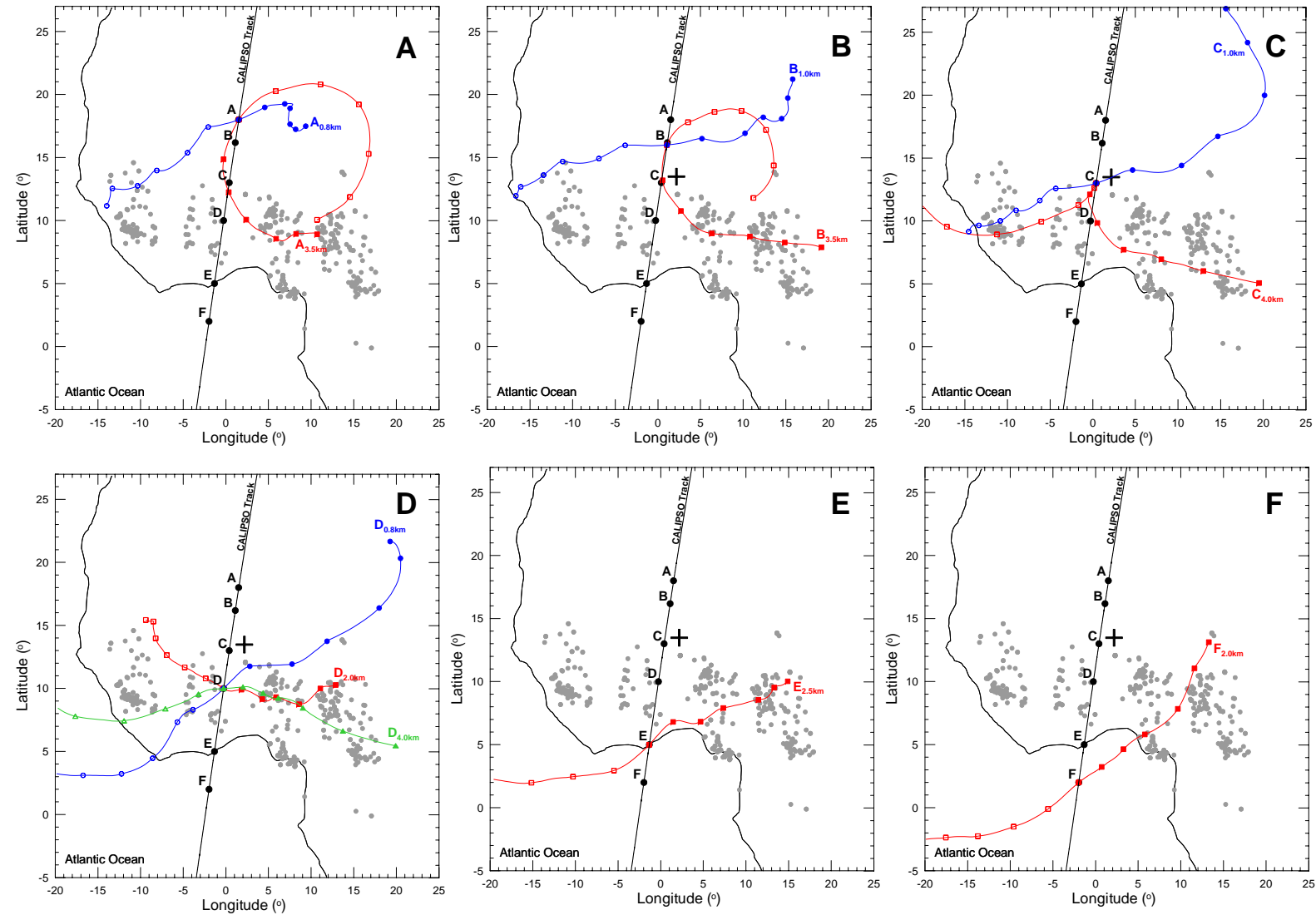

Fig. 11. Four-day backward (closed symbols) and forward (open symbols) trajectories starting from six different locations along the CALIPSO track for the case given in Fig. 9. ATSR fire location is shown as grey dots.

and the biomass burning aerosol layer at points " $A$ " to " $D$ ". These results suggest that the aerosols in the elevated layers $L_{1}^{E}$ and $L_{1}^{F}$ in the south may be a mixture of mineral dust and biomass burning aerosols. Although $\beta_{532}^{\prime}$ peaks at the center of layers $L_{1}^{E}$ and $L_{1}^{F}, \delta$ shows relatively larger values (e.g. $>20 \%$ ) and $L A E$ relatively lower values at the lower part of the layer. Their values at the bottom of the aerosol layer are close to the values obtained for the low level dust layer over the continent and they gradually decrease with height towards values found in elevated biomass burning layers over the continent. This would indicate that layers $L_{1}^{E}$ and $L_{1}^{F}$ have not mixed completely in the vertical.

To trace the origins of the aerosols in each layer we calculated the airmass trajectories, starting at the center of each aerosol layer, for the aerosol layers at the six selected locations " $A$ " to " $F$ " (red dots in Fig. 9b). Over the continent (from points " $A$ " to " $D$ "), Fig. 11 shows that the aerosols confined below approximately $1.5 \mathrm{~km}$ (blue trajectories) originated from the Sahara desert (i.e. they are mainly composed of mineral dust particles) and were advected over the Atlantic ocean, whereas the elevated aerosol layers were mostly transported from the biomass burning areas, as indicated by the gray dots (marking fires). The forward trajectories from points " $A$ " and " $B$ " are spiral clockwise over the desert areas to the northeast of Niamey whereas the forward trajectories from points " $C$ " and " $D$ " travel west towards the west coast of Africa. The trajectories for points " $E$ " and " $F$ " show that the turbid airmasses over the marine atmospheric boundary layer were transported from the biomass burning aerosol regions and are transported in a west to south-westerly direction out over the Tropical Atlantic.

As shown in Sect. 5, enhanced levels of water vapor were consistently observed within the biomass burning aerosol layers relative to the air above and below. Figure 12 shows the radiosonde-derived WVMR and $\theta$ values obtained at Niamey airport at 18:00 UTC on 6 January 2007 and at 00:00 UTC on 8 January 2007, respectively. Unfortunately, the radiosonde data obtained on 7 January 2007 did not have sufficient vertical information. The low WVMR below $1.5 \mathrm{~km}$ is attributed to the dry dust laden air, whereas, the WVMR within the elevated biomass burning aerosol layer between $1.5 \sim 6 \mathrm{~km}$ is higher than in the air above and below the biomass burning aerosol layer. A steep increase in the value of $\theta$ in the upper region of the dust and biomass burning aerosol layers was found. The enhanced radiative heating rate due to the dust and biomass burning aerosols, as well 


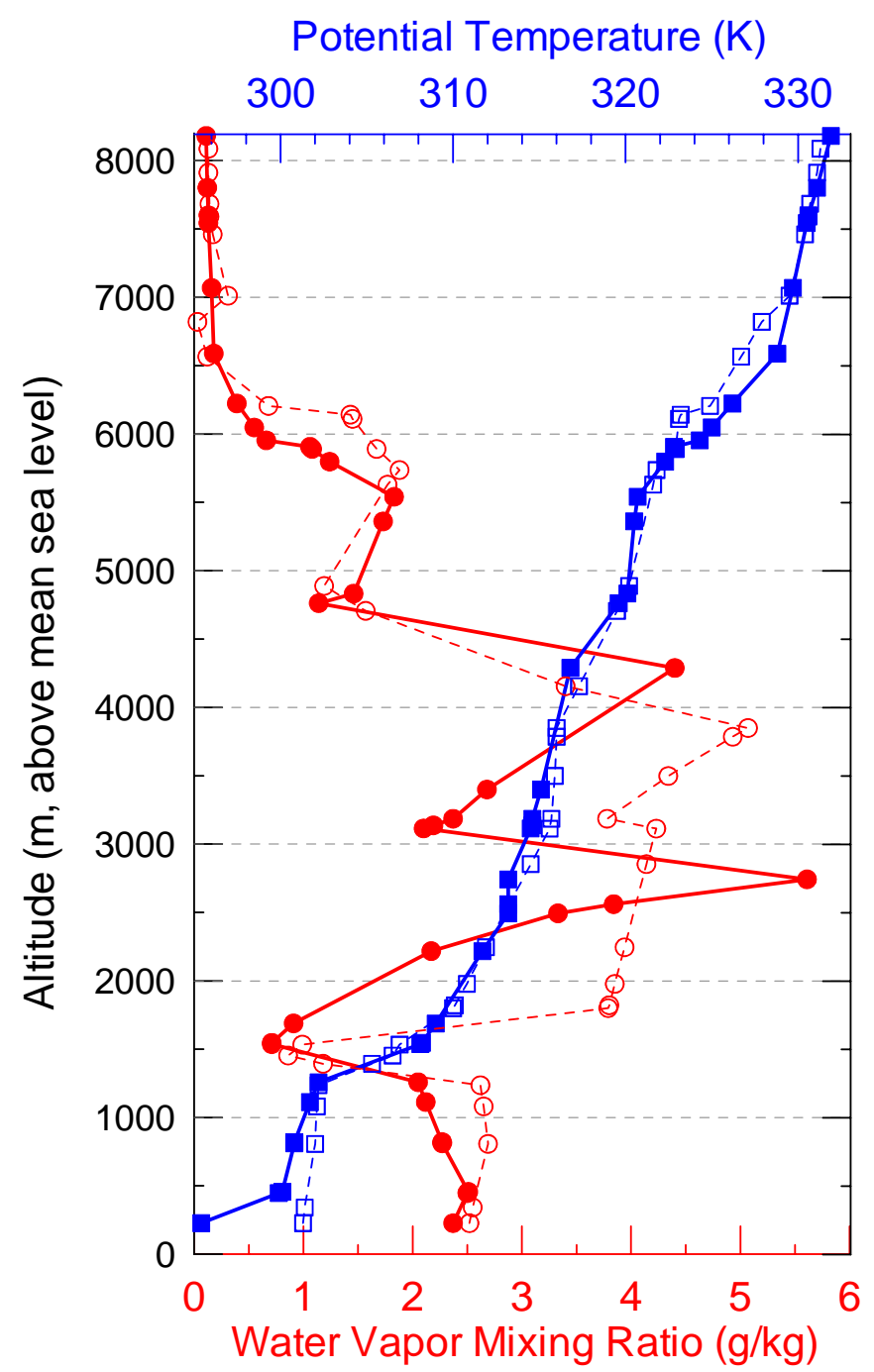

Fig. 12. Radiosonde-derived water vapor mixing ratio (circles) and potential temperature (squares) at Niamey airport at 18:00 UTC on 6 January 2007 (open symbols) and at 00:00 UTC on 8 January 2007 (closed symbols).

as elevated levels of water vapor within the biomass burning aerosol layer, contribute to the increase in static stability across the dust layer (e.g. Carlson and Benjamin, 1979; Kim et al., 2004; Won et al., 2004).

\subsection{Case 2: 18 January 2007}

Figure 13 shows the Aura OMI-derived daily mean UV aerosol index over West Africa on 18 January 2007 and the altitude-orbit cross-section of the total attenuated backscattering intensity along the CALIPSO track around 01:32 UTC on 18 January 2007 (case 2). The lidar backscatter shows a two-layered aerosol structure over the land and a single thick aerosol layer over the ocean; a similar pattern to case 1 . These layers were observed under cloud-free conditions when CALIPSO flew across the center of a highly absorbing aerosol plume.
Figure 14 shows selected vertical profiles of $\beta_{532}^{\prime}, \delta, L A E$ and $\sigma_{532}$ for three locations (points "I" "III" shown in Fig. 13b). We found consistent agreement in the vertical structure of aerosols from the $\beta^{\prime}$ and $\sigma_{532}$ profiles. The values of $\delta, L A E$, and $\sigma_{532}$ clearly discriminate between mineral dust aerosols at low levels $(\delta \approx 25 \%, L A E<0.0$, $\sigma_{532} \approx 0.40 \sim 0.55 \mathrm{~km}^{-1}$ ) and elevated layers of biomass burning aerosols $\left(\delta<10 \%, L A E>1.0, \sigma_{532} \sim 0.05 \mathrm{~km}^{-1}\right.$ in $L_{1}^{\mathrm{I}}$ and $\sim 0.18 \mathrm{~km}^{-1}$ in $L_{1}^{\mathrm{II}}$ ) over the land (points "I" and "II"). The values of $B E R$ are similar to those of case 1 (see Table 1). Again, both $\delta(\sim 10.0 \%)$ and $B E R\left(\sim 0.020 \mathrm{sr}^{-1}\right)$ values of the elevated layer over the ocean off the coast of the African continent (point "III") are intermediate between the values obtained for the mineral dust layer and the biomass burning aerosol layers at points "I" and "II". The $L A E$ value of the elevated layer at point "III" increases with height within the 

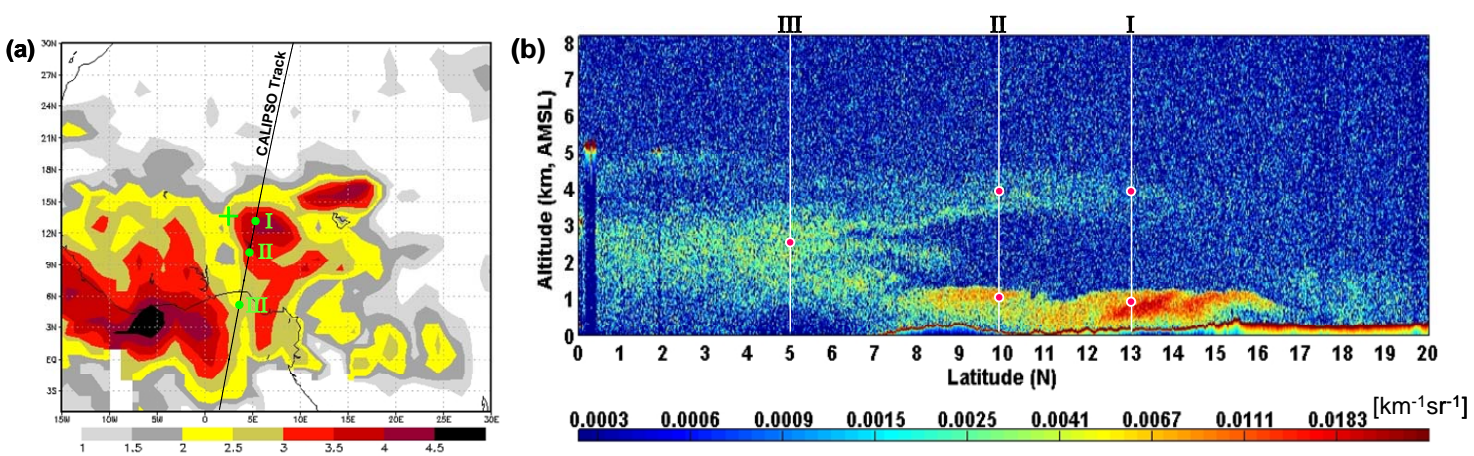

Fig. 13. Same as Fig. 9 but for case 2 involving (a) Aura OMI data on 18 January 2007 and nighttime descending ground track (black line) of CALIPSO at around 01:32 UTC on 18 January 2007 near Niamey airport (crosshair), Niger. The white vertical lines and red dots represent three selected locations ("I"-“III"), and the starting altitudes for backward trajectory calculations (see Fig. 15).

layer. Layer-averaged values of $\delta$ and $L A E$ for each aerosol layer are provided in Table 1 along with heights of the bottom and top of each layer. The results are very similar to those reported in case 1 and strongly suggest that the aerosols in the elevated layer $L_{1}^{\mathrm{III}}$ are a mixture of mineral dust and biomass burning aerosols.

Figure 15 shows the airmass trajectories starting at the center of each aerosol layer. The trajectories from locations "I" and "II", over the continent, indicate that the dustrich aerosols confined below approximately $1.5 \mathrm{~km}$ originate from the Saharan desert. These are later advected over the Atlantic Ocean to the west of the CALIPSO track. The elevated aerosol layers are mostly transported from the biomass burning areas, as indicated by the gray dots (marking fires), and are advected northwest toward the Sahara then back south and west towards the tropical Atlantic. The trajectories for point "III", off the coast, show that the airmass was transported from the biomass burning aerosol regions and continues to travel in a westerly or southwesterly direction over the tropical Atlantic. As in case 1, we find higher levels of water vapor within the biomass burning aerosol layer relative to the air above and below (see red line with closed symbols in Fig. 12) based on the radiosonde measurement from Niamey at 00:00 UTC on 18 January 2007.

\section{Summary and conclusions}

We have investigated tropospheric aerosol transport over West Africa and the associated meteorological conditions during the AMMA dry season experiment, which occurred in West Africa in January-February 2006. This study combines data from ULA-based and ground-based lidars, airborne insitu aerosol and gas measurements, standard meteorological measurements, satellite-based aerosol measurements, airmass trajectories, and radiosonde measurements.
We identified the presence of coarse mineral dust aerosol and very dry air at low levels $(<2 \mathrm{~km})$, originating from the Sahara desert. This air eventually mixes with biomass burning aerosols within the Sahel and is advected over the Tropical Atlantic Ocean. At higher levels $(2-5 \mathrm{~km})$ we observed biomass burning aerosols that originated from the biomass burning regions to the south $\left(<10^{\circ} \mathrm{N}\right)$. The prevailing winds at low-levels was from the northeast but the winds veered with height turning to a southerly or southeasterly in lower part of the middle troposphere $(850-600 \mathrm{hPa})$. We found higher concentrations of water vapor within the elevated biomass burning aerosol layers relative to the air above or below. This relatively warm and moist airmass is advected upward over the biomass burning region through a synoptic ascending motion over Inter-Tropical Discontinuity (ITD) zone. These findings are consistent with the observations previously reported from AMMA SOP-0/DABEX and provide supporting evidence for the synoptic-scale aerosol transport pattern illustrated by Haywood et al., (2008).

Aerosol vertical distributions measured from the spacebased lidar CALIOP, onboard CALIPSO, showed that this pattern occurred on the following year (January 2007), confirming that this circulation is a repeating feature of the African monsoon dry season. CALIOP identified the presence of depolarizing $(\delta \sim 30 \%)$, large-sized $(L A E \leq 0)$ dust particles at low levels $(<1.5 \mathrm{~km})$ and elevated layers of biomass burning smoke aerosols (depolarization ratio: $<10 \%$ ) between 2 and $5 \mathrm{~km}$. The layer-averaged $B E R$ values were $0.015 \sim 0.018 \mathrm{sr}^{-1}$ for the elevated biomass burning aerosol layers and $0.026 \sim 0.028 \mathrm{sr}^{-1}$ for the dust-rich surface layers. These dust and biomass burning aerosol layers seem to mix to form a single layer of mixed highly-scattering aerosol over the Tropical Atlantic Ocean, as indicated by intermediate values of particle depolarization ratio $(10 \sim 17 \%)$, lidar Ångström exponent $(0.16 \sim 0.18)$, and layer-averaged $B E R$ value $\left(0.0021 \sim 0.0022 \mathrm{sr}^{-1}\right)$. As observed elsewhere (e.g. Léon et al., 2001), this highly-scattering continental airmass is advected over the marine atmospheric boundary 

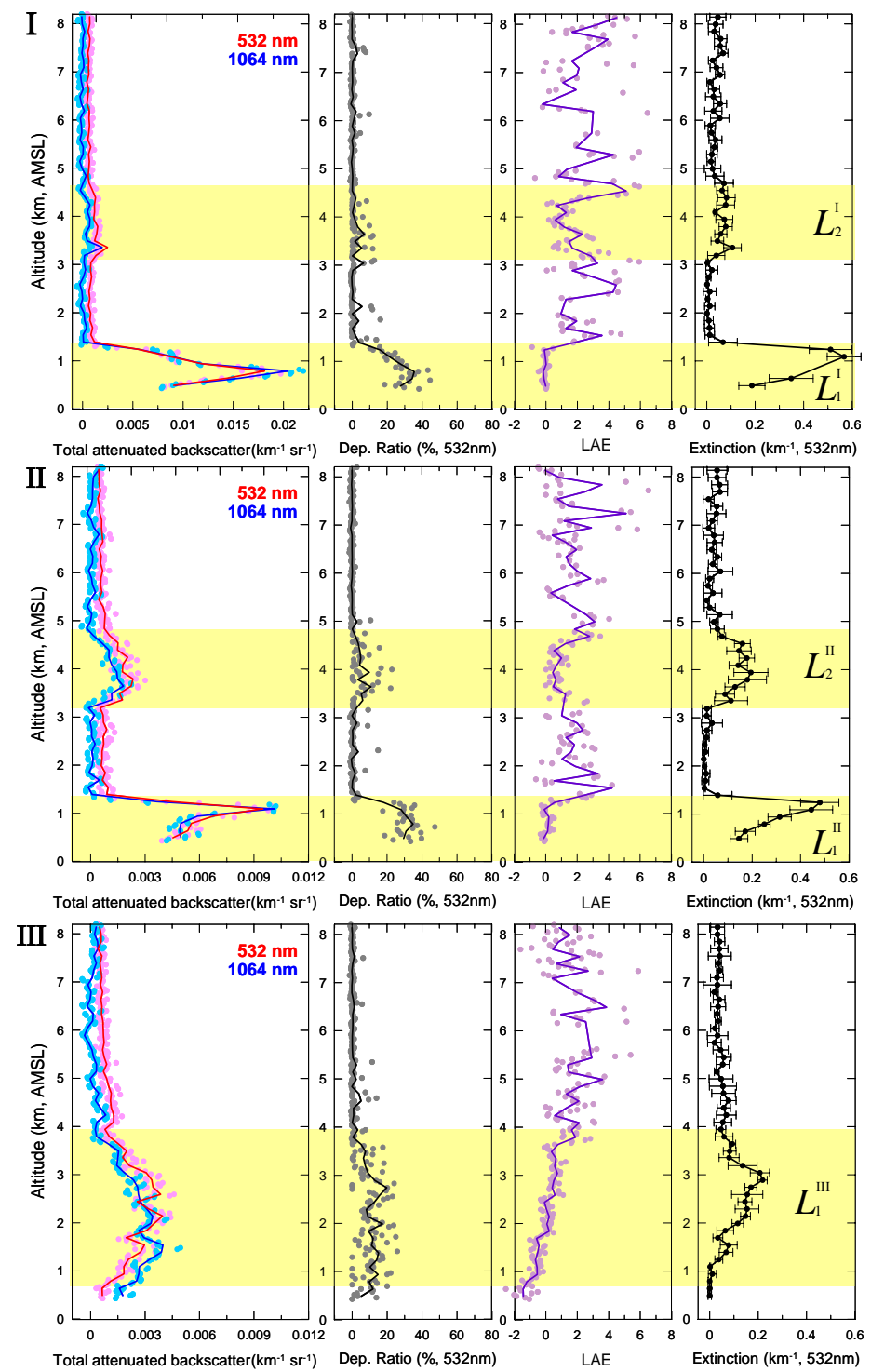

Fig. 14. Same as Fig. 10, except for the three locations ("I"-"III") along the CALIPSO track on 18 January 2007 (see Table 1 and Fig. 13 for details).
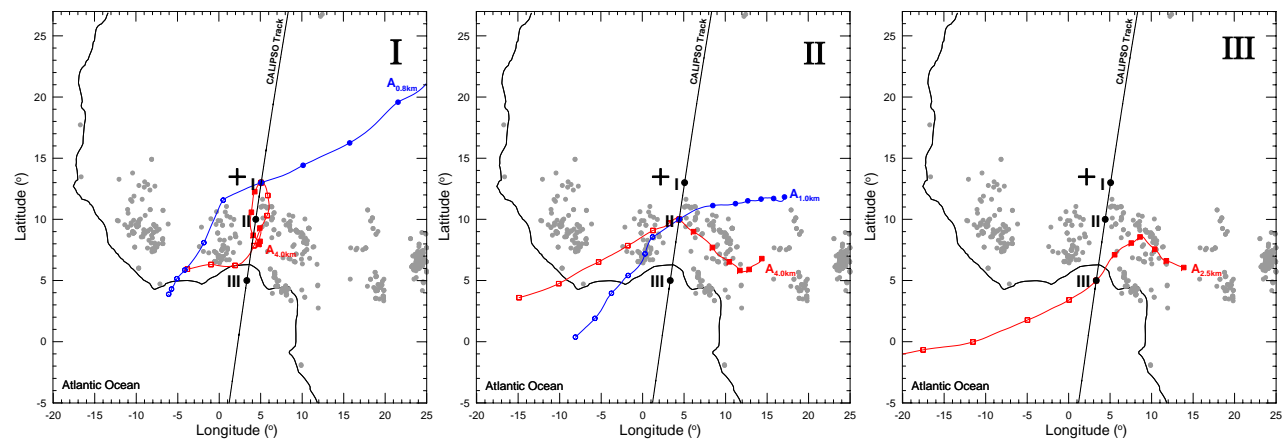

Fig. 15. Three-day backward (closed symbols) and forward (open symbols) trajectories starting from three locations along the CALIPSO track at 02:00 UTC on 18 January 2007. 
layer. These observations imply there may be complex interactions (e.g. internal/external chemical mixing and associated optical property change) between the dust and biomass aerosols. Such changes have implications on the radiative budget of the atmosphere and the climate system over the Sahelian region and Atlantic Ocean. They also show a strong contrast in aerosol vertical distributions and the degree of vertical mixing within airmasses over the continent and the ocean.

Acknowledgements. This study was supported by the BK21 program in School of Earth and Environmental Sciences (SEES), Seoul National University (SNU), a post-doc grant from the French Ministry of Research, the French Space Agency Centre National d'Etudes Spatiales (CNES), and the Commissariat à l'Energie Atomique (CEA). Based on a French initiative, AMMA was built by an international scientific group and funded by a large number of agencies, especially from France, UK, US, and Africa. This study has been the beneficiary of a major financial contribution from the European Community's Sixth Framework Research Program. Detailed information on scientific coordination and funding is available on the AMMA International web site http://www.amma-international.org. The CALIPSO data were obtained from the NASA Langley Research Center Atmospheric Science Data Center (ASDC) via on-line web orders. We are extremely grateful to the entire CALIPSO, MISR, OMI, ATSR science teams for providing the data.

Edited by: F. J. Dentener

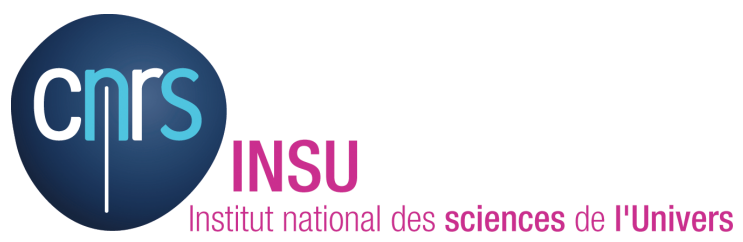

The publication of this article is financed by CNRS-INSU.

\section{References}

Arino, O., Plummer, S. and Defrenne, D.: Fire disturbance; the ten years time series of the ATSR world fire atlas, available at: http://dup.esrin.esa.it/ionia/wfa/references.asp, MERIS-AATSR workshop 2005, Italy, 2005.

Berthier, S., Chazette, P. , Couvert, P. , Pelon, J., Dulac, F., Thieuleux, F., Moulin, C., and Pain, T.: Desert dust aerosol columnar properties over ocean and continental Africa from Lidar in-Space Technology Experiment (LITE) and Meteosat synergy, J. Geophys. Res., 111, D21202, doi:10.1029/2005JD006999, 2006.

Cachier, H. and Ducret, J.: Influence of biomass burning on equatorial African rains, Nature, 352, 228-230, 1991.

Capes, G., Johnson, B., McFiggans, G., Williams, P. I, Haywood, J., and Coe, H.: Aging of biomass burning aerosols over West Africa: Aircraft measurements of chemical composition, microphysical properties, and emission ratios, J. Geophys. Res., 113, D00C15, doi:10.1029/2008JD009845, 2008.
Carlson, T. N. and Benjamin, S. G.: Radiative heating rates for Saharan dust, J. Atmos. Sci., 37, 193-213, 1979.

Cattrall, C., Reagan, J., Thome, K., and Dubovik, O.: Variability of aerosol and spectral lidar and backscatter and extinction ratios of key aerosol types derived from selected Aerosol Robotic Network locations, J. Geophys. Res., 110, D10S11, doi:10.1029/2004JD005124, 2005.

Chazette, P.: The monsoon aerosol extinction properties at Goa during INDOEX as measured with lidar, J. Geophy. Res., 108, 4187, doi:10.1029/2002JD002074, 2003.

Chazette, P., Sanak, J., and Dulac, F.: A new approach for aerosol profiling with a lidar onboard an ultra light aircraft: application to the African Monsoon Multidisciplinary Analysis, Environ. Sci. Technol., 41(24), 8335-8341, 2007.

Christopher, S. A., Gupta, P., Haywood, J., and Greed, G.: Aerosol Optical Thickness over North Africa, Part 1: Devopment of a product for model validation using OMI, MISR, AERONET, J. Geophys. Res., 113, D00C04, doi:10.1029/2007JD009446, 2008.

Cuesta, J., Edouart, D., Mimouni, M., Flamant, P., et al.: Multiplatform observations of the seasonal evolution of the Saharan atmospheric boundary layer in Tamanrasset, Algeria, in the framework of the African Monsoon Multidisciplinary Analysis field campaign conducted in 2006, J. Geophys. Res., 113, D00C07, doi:10.1029/2007JD009417, 2008.

Draxler, R. R. and Rolph, G. D.: HYSPLIT (HYbrid SingleParticle Lagrangian Integrated Trajectory) Model access via NOAA ARL READY Website (http://www.arl.noaa.gov/ready/ hysplit4.html), NOAA Air Resources Laboratory, Silver Spring, MD, 2003.

Dulac, F., Chazette, P., Gomes, L., Chatenet, B., Berger, H., and Vinicula dos Santos, J. M.: A method for aerosol profiling in the lower troposphere with coupled scatter and meteorological rawinsondes and first data from the tropical Atlantic off Sahara, J. Aerosol Sci., 32, 1069-1086, 2001.

Eck, T., Holben, B., Ward, D., Mukelabai, M., et al.: Variability of biomass burning aerosol optical characteristics in southern Africa during the SAFARI 2000 dry season campaign and a comparison of single scattering albedos estimates from radiometric measurements, J. Geophys. Res., 108(D13), 8477, doi:10.1029/2002JD002321, 2003.

Freudenthaler, V., Esselborn, M., Wiegner, M., Heese, B., et al.: Depolarization ratio profiling at several wavelengths in pure Saharan dust during SAMUM 2006, Tellus, 61(1), 165-179, 2008.

Gobbi, G. P., Barnaba, F., Van Dingenen, R., Putaud, J. P., Mircea, M., and Facchini, M. C.: Lidar and in situ observations of continental and Saharan aerosol: closure analysis of particles optical and physical properties, Atmos. Chem. Phys., 3, 2161-2172, 2003, http://www.atmos-chem-phys.net/3/2161/2003/.

Gobbi, G. P., Barnaba, F., and Ammannato, L.: The vertical distribution of aerosols, Saharan dust and cirrus clouds in Rome (Italy) in the year 2001, Atmos. Chem. Phys., 4, 351-359, 2004, http://www.atmos-chem-phys.net/4/351/2004/.

Haywood, J. M. and Boucher, O.: Estimates of the direct and indirect aerosols: a review, Rev. Geophys., 38, 513-543, 2000.

Haywood, J., Francis, P., Osborne, S., Glew, M., Loeb, N., et al.: Radiative properties and direct radiative effect of Saharan dust measured by the C-130 aircraft during 
SHADE: 1, Solar spectrum, J. Geophys. Res., 108(D18), 8577, doi:10.1029/2002JD002687, 2003.

Highwood, E. J., Haywood, J. M., Silverstone, M. D., Newman, S. M., and Taylor, J. P.: Radiative properties and direct effect of Saharan dust measured by the C-130 aircraft during Saharan Dust Experiment (SHADE): 2, Terrestrial spectrum, J. Geophys. Res., 108(D18), 8578, doi:10.1029/2002JD002552, 2003.

Haywood, J. M., Pelon, J., Formenti, P., Bharmal, N. A., Brooks, M., Capes, G., Chazette, P., Chou, C., Christopher, S., Coe, H., Cuesta, J., Derimian, Y., Desboeufs, K., Greed, G., Harrison, M., Heese, B., Highwood, E. J., Johnson, B. T., Mallet, M., Marticorena, B., Marsham, J., Milton, S., Myhre, G., Osborne, S. R., Parker, D. J., Rajot, J.-L., Schulz, M., Slingo, A., Tanre, D., and Tulet, P: Overview of the Dust and Biomass burning Experiment and African Monsoon, Multidisciplinary Analysis Special Observing Period-0, J. Geophys. Res., 113, D00C06, doi:10.1029/2007JD009451, 2008.

Hobbs, P.: Clean air slots amid atmospheric pollution, Nature, 415, 861, 2002.

Hobbs, P. V.: Clean air slots amid dense atmospheric pollution in southern Africa, J. Geophy. Res., 108(D13), 8490, doi:10.1029/2002JD002156, 2003.

Johnson, B. T., Osborne, S. R., and Haywood, J. M.: Aircraft measurements of biomass-burning aerosols over West Africa during DABEX, J. Geophys. Res., 113, D00C06, doi:10.1029/2007JD009451, 2008.

Kahn, R. A., Gaitley, B. J., Martonchik, J. V., Diner, D. J., Crean, K. A., and Holben, B.: Multiangle Imaging Spectroradiometer (MISR) global aerosol optical depth validation based on 2 years of coincident Aerosol Robotic Network (AERONET) observations, J. Geophys. Res., 110, D10S04, doi:10.1029/2004JD004706, 2005.

Kalnay, E., Kanamitsua, M., Kistlera, R., Collinsa, W., Deavena, D., et al.: The NCEP/NCAR 40-year reanalysis project, Bu. Am. Meteorol. Soc., 77, 437-470, 1996.

Keil, A. and Haywood, J. M.: Solar radiative forcing by biomass burning aerosol particles during SAFARI 2000: A case study based on measured aerosol and cloud properties, J. Geophys. Res., 108(D13), 8467, doi:10.1029/2002JD002315, 2003.

Kim, S.-W., Yoon, S.-C., Jefferson, A., Won, J.-G., Dutton, E. G., Ogren, J. A., and Anderson, T. L.: Observation of enhanced water vapor in Asian dust layer and its effect on atmospheric radiative heating rates, Geophys. Res. Lett., 31, L18113, doi:10.1029/2004GL020024, 2004.

Kim, S.-W., Berthier, S., Raut, J.-C., Chazette, P., Dulac, F., and Yoon, S.-C.: Validation of aerosol and cloud layer structures from the space-borne lidar CALIOP using a ground-based lidar in Seoul, Korea, Atmos. Chem. Phys., 8, 3705-3720, 2008, http://www.atmos-chem-phys.net/8/3705/2008/.

Kistler, R., Kalnay, E., Collins, W., Saha, S., White, G., Woollen, J., Chelliah, M., Ebisuzaki, W., Kanamitsu, M., Kousky, V., van den Dool, H., Jenne, R., and Fiorino, M.: The NCEP-NCAR 50-Year Reanalysis: Monthly Means CD-ROM and Documentation, Bu. Am. Meteorol. Soc., 82, 247-268, 2001.

Klett, J. D.: Stable analytical inversion solution for processing lidar returns, Appl. Optics, 20(2), 211-220, 1981.

Klett, J. D.: Lidar inversion with variable backscatter/extinction ratios, Appl. Optics, 24(11), 1638-1643, 1985

Knippertz, P., Ansmann, A., Althausen, D., Muller, D., Tesche, M.,
Bierwirth, E., Dinter, T., Muller, T., von Hoyningen-Huene, W., Schepanski, K., Wendisch, M., Heinold, B., Kandler, K., Petzold, A., Schultz, L., and Tegen, I.: Dust mobilization and transport in the northern Sahara during SAMUM; A meteorological overview, Tellus, 61B, 12-31, 2009

Labonne, M., Breon, F.-M., and Chevallier, F.: Injection height of biomass burning aerosols as seen from a spaceborne lidar, Geophys. Res. Lett., 34, L11806, doi:10.1029/2007G1029311, 2007.

Léon, J.-F., Chazette, P., Dulac, F., Pelon, J., Flamant, C., Bonazzola, M., Foret, G., Alfaro, S. C., Cachier, H., Cautenet, S., Hamonou, E., Gaudichet, A., Gomes, L., Rajot, J. L., Lavenu, F., Inamdar, S. R., Sarode, P. R., and Kadadevarmath, J. S.: Large scale advection of continental aerosols during INDOEX, J. Geophys. Res., 106(D22), 28427-28440, 2001.

Léon, J.-F., Tanré, D., Pelon, J., Kaufman, Y. J., Haywood, J., and Chatenet, B.: Profiling of a Saharan dust outbreak based on a synergy between active and passive remote sensing, J. Geophys. Res. 108, 8575, doi:10.1029/2002JD002774, 2003.

Magi, B. I., Hobbs, P. V., Schmid, B., and Redemann, J.: Vertical profiles of light scattering, light absorption, and single scattering albedo during the dry, biomass burning season in southern Africa and comparisons of in situ and remote sensing measurements of aerosol optical depths, J. Geophys. Res., 108(D13), 8504, doi:10.1029/2002JD002361, 2003.

Marticorena, B. and Bergametti, G.: Two-year simulations of the seasonal and interannual changes of the Saharan dust emissions, Geophys. Res. Lett., 23(15), 1921-1924, 1996.

Myhre, G., Berntsen, T. K., Haywood, J. M., Sundet, J. K., Holben, B. N., Johnsrud, M., and Stordal, F.: Modeling the radiative impact of mineral dust during the Saharan Dust Experiment (SHADE) campaign, J. Geophys. Res., 108(D18), 8579, doi:10.1029/2002JD002566, 2003.

Osborne, S. R., Johnson, B. T., Haywood, J. M., Baran, A., McConnell, C. L., and Harrison, M.: Physical and optical properties of mineral dust aerosol during the Dust and Biomass burning Experiment (DABEX), J. Geophys. Res., 113, D00C03, doi:10.1029/2007JD009551, 2008.

Raut, J.-C. and Chazette, P.: Radiative budget in the presence of multi-layered aerosol structures in the framework of AMMA SOP-0, Atmos. Chem. Phys., 8, 6839-6864, 2008, http://www.atmos-chem-phys.net/8/6839/2008/.

Sauvage, B., Thouret, V., Cammas, J.-P., Gheusi, F., Athier, G., and Nédélec, P.: Tropospheric ozone over Equatorial Africa: regional aspects from the MOZAIC data, Atmos. Chem. Phys., 5, 311335, 2005, http://www.atmos-chem-phys.net/5/311/2005/.

Sauvage, B., Gheusi, F., Thouret, V., Cammas, J.-P., Duron, J., Escobar, J., Mari, C., Mascart, P., and Pont, V.: Medium-range midtropospheric transport of ozone and precursors over Africa: two numerical case studies in dry and wet seasons, Atmos. Chem. Phys., 7, 5357-5370, 2007, http://www.atmos-chem-phys.net/7/5357/2007/.

Swap, R. J., Annegarn, H. J., Suttles, J. T., King, M. D., Platnick, S., Privette, J. L., and Scholes, R. J.: Africa burning: A thematic analysis of the Southern African Regional Science Initiative (SAFARI 2000), J. Geophys. Res., 108(D13), 8465, doi:10.1029/2003JD003747, 2003.

Tafuro, A. M., Barnaba, F., De Tomasi, F., Perrone, M. R., and Gobbi, G. P.: Saharan dust particle properties over the central 
Mediterranean, Atmos. Res., 81, 67-93, 2006.

Tanré, D., Haywood, J., Pelon, J, Léon, J.-F., Chatenet, B., Formenti, P., et al.: Measurement and modeling of the Saharan dust radiative impact: Overview of the Saharan Dust Experiment (SHADE), J. Geophys. Res., 108(D18), 8574, doi:10.1029/2002JD003273, 2003.

Winker, D. M., Hunt W. H, and McGill, M. J.: Initial performance assessment of CALIOP, Geophys. Res. Lett., 34, L19803, doi:10.1029/2007GL030135, 2007.

Won, J.-G., Yoon, S.-C., Kim, S.-W., Jefferson, A., Dutton, E. G., and Holben, B.: Estimation of direct radiative forcing of Asian dust aerosols with sun/sky radiometer and lidar measurement at Gosan, Korea, J. Meteorol. Soc. Jpn., 82(1), 115-130, 2004.
Yoon, S.-C., Kim, S.-W., Kim, J., Sohn, B.-J., Jefferson, A., Choi, S.-J., Cha, D.-H., Lee, D.-K., Anderson, T. L., Doherty, S. J., and Weber, R. J.: Enhanced Water Vapor in Asian Dust Layer: Entrainment Processes and Implication for Aerosol Optical Properties, Atmos. Environ., 40(13), 2409-2421, 2006.

Young, S., Winker, D., Vaughan, M., Hu, Y., and Kuehn, R.: CALIOP Algorithm Theoretical Basis Document, Part 4: Extinction Retrieval Algorithms, Data Products Catalog, PC-SCI-202 Part 4, NASA Langley Research Center, available at: http://www-calipso.larc.nasa.gov/resources/pdfs/ PC-SCI-202_Part4_v1.0.pdf, Hampton, VA, 2008. 